\title{
THE POTAMOGETONS IN RELATION TO POND CULTURE
}

\author{
A THESIS \\ Presented to the Faculty of the Graduate School \\ of Cornell University for the DEgreE OF \\ DOCTOR OF PHILOSOPHY
}

BY

EMMELINE MOORE

$\vdots \vdots$

Reprinted from BULIETIN OF THE BUREAU OF FISHERIES, Vol. XXXIII, 1913 Document No, 816 
i 


\title{
THE POTAMOGETONS IN RELATION TO POND CULTURE
}

\author{
A THESIS \\ Presented to the Faculty of the Graduate School \\ of Cornell University for the degree of \\ DOCTOR OF PHILOSOPHY
}

BY

EMMELINE MOORE

Reprinted from BULLETIN OF THE BUREAU OF FISHERIES, Vol, XXXIII, 1913 Document No. 815 


$$
=\frac{2,19}{50}
$$


THE POTAMOGETONS IN RELATION TO POND CULTURE

*

\author{
By Emmeline Moore
}

Contribution from the Department of Limnology', Cornell L'niversity' 



\section{CONTENTS.}

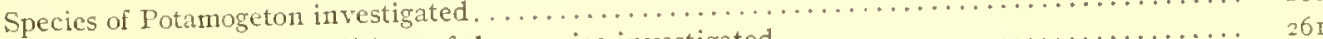

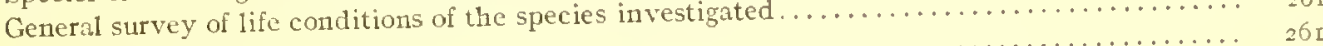

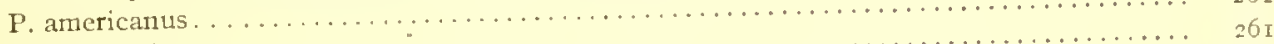

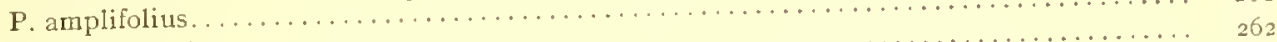

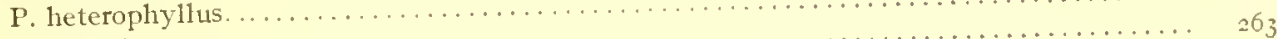

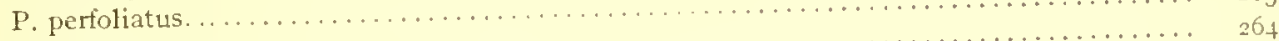

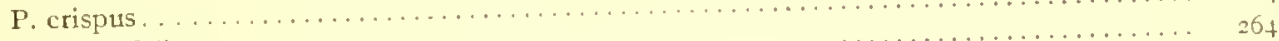

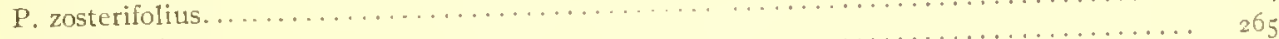

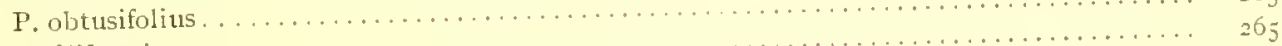

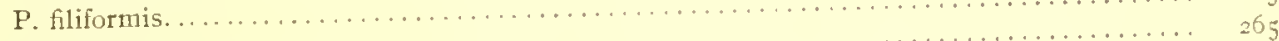

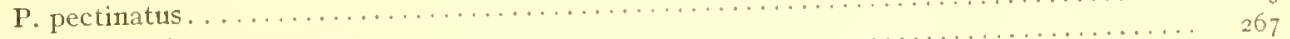

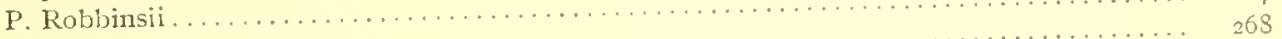

Summary of cultural features. . . . . . . . . . . . . . . . . . . . . . . . . . . . . . . . . .

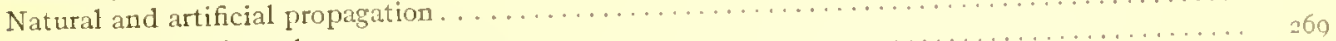

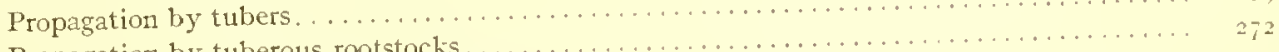

Propagation by tuberous rootstocks. . . . . . . . . . . . . . . . . . . . . . . . . . . . . . .

Propagation by subterranean stems not tuberous. . . . . . . . . . . . . . . . . . . . . . . .

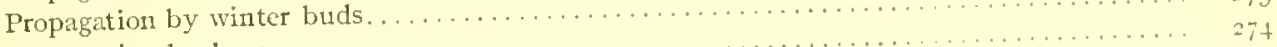

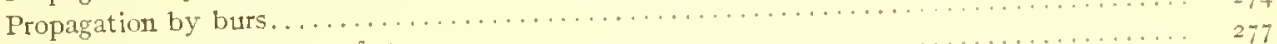

Propagation by fragments of stems. . . . . . . . . . . . . . . . . . . . . . . . . . . . .

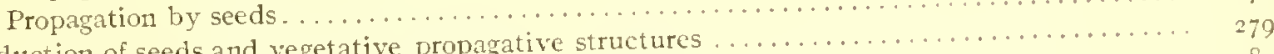

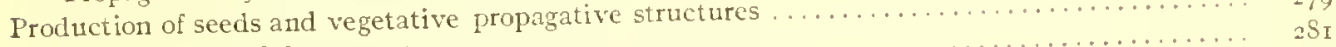

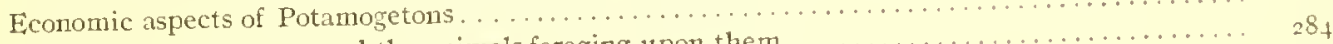

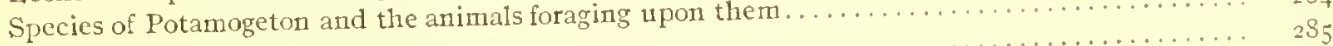

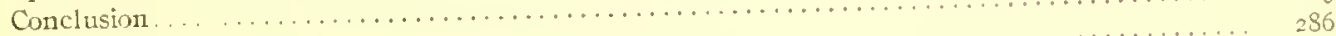

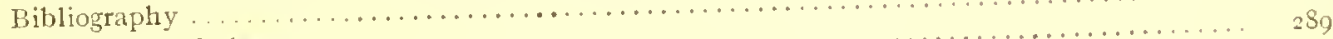

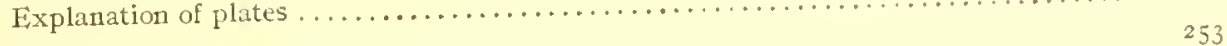





\title{
THE POTAMOGETONS IN RELATION TO POND CULTURE.
}

\author{
\% \\ By EMMELINE MOORE, \\ Contribution from the Department of Limnology, Cornell Liniversity. \\ $e^{2}$ \\ NTRODUCTION.
}

The cultivation of lakes, ponds, and streans follows as a natural consequence the biological investigation of the aquatic life within them. Ilerbivores and carnivores live their life in the water, and if we ponder over their means of sustenance we are struck by the fact that the natural food supply has rarely been augmented by cultural methods.

"The larger aquatic plants," says Pond (1903), "form a link in the chain of nutritive relations that stretches from the water and soil to the higher fishes." If such is the importance of these plants, the great mass of regetation which comes to maturity each season is a national asset. Yet the ammual yield has never been estimated or given a place in the Govermment crop reports.

Aquatic plants have contested for possession of the waters much as the grasses have contended for suprenacy on land, until it nay be said that the dominant forage crop of our lakes, ponds, and streans is to be found among the pondweeds, the Potamogetons. Variety in form, adaptability to euvironment, and diversity in range have all contributed their share in giving prominence to this group and in furthering a natural resonrce whose propagation and control are vital factors in the economic relations of the life of inland waters.

The object of this investigation is to present such observations and experiments on the natural and artificial propagation of the Potamogetons as will render cultural methods economical and practical.

The work herein recorded was carried on at Cornell University under the direction of Dr. James C. Needhan, to whom I wish to express my grateful thanks for help and suggestion.

\section{HISTORICAL.}

The cultivation of aquatic plants was an ancient occupation, one which concerned itself with the beautification of pools and funntains. In modern times, too, aquatic plants have been used in variety and profusion in the ornamentation of artificial or natural ponds. But the cultivation of aquatics from an economic standpoint is a new idea, so new, in fact, that data regarding it are just beginning to appear in bulletin form in the Government compilations of scattered and isolated experiments. In the bulletins plants of the genus Potamogeton have received the larger nneasure of notice because observations on the feeding habits of animals associated with them point to the important roble of these plants in the economy of nature. 
Further contribution to the present status of the Potamogetons incorporates of necessity a considerable body of observation pertaining to the systematic, morphological, and biological aspects of this group, and renders it highly desirable to set forth the historical background of each of these three phases of the subject.

John CirRARDLi, 2633

A beginning in the clissification of the Potamogetons was made by the old herbalists, medical men, who fonnd it necessury tu study plants in detail in orch to diserininate the kinds employed for different purposes. The special virtue in Potanogetons, for exanple, resided in the leaves, which wore applical to reduce inflanumation. In the herbial of Juln Gerarde the group Potamogeton ( $/$ 'otamogiton in the old spelling and pondweed or water spitie in the common parlance of the time) consisted of four speeies-a brosd-leated pondweed, a nurrow-leated pondweed, a small pondwed, and a long sharp-leaved pondwed. There was a figure of the entire plunt accompunied by the Latin and English name. Then followed the "description, plise, time, names, niture, and virtues agreeing with the best received opinims." A "fennel-herbed water milfoile" illustrited by a ligure casily recognized as onr fennel-1eited pundweed, Potamogiton pectinatus, was given a plice anlong the Myriophyllums. Sucle was one of the earliest attempts to classify the group.

CHAMISSO AND SCHLECHTENDAL, 1827

The first injortant monograph of the Potamogetons was the work of Ciamisso and Sclilechtendal, who, in Linnea, volune 2,1827 , svstematized the results if scientific observation during the latler part of the eiglutenth and the beginning of the nincesenth centuries. Under the family nithe of Alisnace $2 x$ species were described and illustrated by drawings of fruit and leat, including among them many of the common and widely distributed species of to-day. Several other Potamogetons wore listed as uncertain in position and difficult (1) classify, a eondition which holds as true to-dity as then, when Chanisso and Selilechtendal struggled to bring orter out of chaos in this puzzling group and reended this purtinent observation: "Species Iotanugetonum habitum mutantes in alias sape transire videntur, alienteque speeici habitum menticntes serutatoram irrident," whicl transliated is, "Species of Putimugeton clunging their habit seem often to pass into others, and feigning the laabit of other species frafte research."

REICHENBACII, 1845 .

Reiclicnbach's nonograpl of the Potamogetons, in his Ieones Filore Germanice et Helvetica, followed in 1845 . More intensive in scope than any" preceding work, it marked a distinct advance both in the nutlod of description and in the matter of illustration. Several reproductions, especially of flower and fruit, which were drawn with grcat cleamess and accuracy, have found their way in the latest authoritative works on the subject. In this monograph the autlor introduced the figure of the so-called "bur," the vegetative prupagative body of I'. chipus Linnzus, though he apparently did not recognize its signifieance in the rapid propagation of this species. It is interesting to note that the figure is inserted withon further description ur comment. Horever, it is erroneonsty drawn, and the error las been eupied time without end

IRMISC11, 185 I.

Thilo Irnisch, in a published note in Flora, rs 51 , first recognized the presence of tubers on $P$. pectinatus.

Agardh, 1852 .

A year läter J. C. Agardh, in Verhandhngen der K. Sehwedischen Akademie der Wissensehaflen, recorded several ubservations on the tubers of this species of Potanogeton.

Clos, D., I856.

I. Clis was the first to publish an account of the origin of the "bur" of cripus, thougl his ulservations are incomplete regurding both their develupment and their germination.

IRMISCH, is 5 S.

In a remarkible monograpja by Irmiscli, C̈ber cinige Arten aus cler naturlichen Pflanzenfamilie der Potamogetun, the history of the development of the tuberous growths on $l$ '. fectinatus is recorded and their morpluogicit and anatomical structure described. The author states that, at the end of the vegeta- 
tive period in the fall, the shoots of recent formation have a singular appearance, the last two thin internodes bearing tubers at the end. At first the tuberousend resembles a conical terminal shoot or bud surrounded by scales. Intemodes make their appearance and soon become thickened; eventually the scales split and disclose a tuber of two swollen internodes. Simultaneously a slender bud forms at the distal end of the tuber, and axial outgrowths develop from the sides that bespeak the shoots of ordinary branches. These axial shoots in turn develop swollen internodes which follow two thinner ones as in the preceding case and produce a series of tubers dicliasial in form. The excellent series of drawings by means of which the author depicts the transition from internode to tuber leaves nothing to be desired in the morphological interpretation of them. They are clearly two modified internodes.

Tuber-bearing shoots grow out of the upper leaf axils also, and follow the usual development of generations of internodes with leafy shoots, besides the tuber-bearing ones in two or three series. The anatom. ical structure of the tuber resembles that of the stem excepting that all tissue not fibro-vascular is filled with starch. The observations on $P$. obtusifolizs are incomplete, but the presence of winter buds is noted. For $P$. natans and $P$. lucens the morphology of the rootstock, stem, and shoot is completely determined, and the details are clearly shown in the drawings. The method of branching is fundamentally the same in the two species. In brief, the growing tips of the rootstocks branch dichotomously, giving an erect axis and a horizontal one. Each generation of the developing rootstock brings forth two horizontal internodes and a bud which is the incipient erect axis. The terminal bud at the end of the horizontal axis reproduces this condition as long as the plant lives. In the development of the erect shoot, the scales, usualiy three in number, grade into stipular sheath, phyllodes, and foliage leaves. A two-fifths arrangement of leaves is noted and the shoots follow the same order. The winter condition of $P$. lucens consists of rootstocks by means of which the plant propagates itself rapidiy in the spring. The internodes of these rootstocks are shorter and thicker tlian the ordinary ones and are borne in a succession of three or more witl terminal and axillary buds containing the incipient axes of the horizontal and erect shoots.

Irmiseh made observations also on $P$. crispus, investigating especially the "burs" or propagative shoots, although this work was anticipated in part by D. Clos in his Mode de Propagation particulier au Potomogeton crispus I. Irmisch, however, found two forms of the bur of crisfus, the slender spicular bur as well as the stout, lorny, denticulate one observed by Clos. The former bur he obscrved growing in the axils of detached shoots in late autumn and afterwards breaking away from the axils and settling in the mud. The origin of the latter form le did not observe, but lie found it in the muddy bottoms of ponds in great abundance. These "burs" or modified twigs, as Irmisch sometimes called them, he con. sidered important examples of propagative structures.

In connection with these plants, Irmisch first pointed out the "Scheiden-Schüppchen, squamulæ intravaginales," scale-like structures developed at the leaf bases, having as a possible function the production of slime or mucilage for the protection of young and slender shoots.

This monograph is of special importance in presenting the morphological data of a few species of Potamogeton. From time to time further contributions have been made to the subject by other investigators in the field, but this still remains the greatest work of its kind.

As a result of these studies on the tubers of $P$. pectinatus, the rootstocks of $P$. lucens, and tine burs of $P$. crispu, Irmisch came to appreciate the advantage of artificial propagation in this group and remarked in conclusion, in an observation that is prophetic of present day interest. "That many of the Potamogetons, as well as other aquatic plants, possess in a singular way that possibility of domestication which has given us the tame animals from the wild ones."

RoBBINS, I867.

Thus far the work of the Potamogetons was confined principally to European species. In $186_{7}$, however, the American species were reduced to something like a complete intelligible systematic shape by Dr. G. W. Robbins, whose descriptions, as far as they came witlin the range, were incorporated in Gray's Manual, edition 5. Later descriptions of the western species were published as they became known.

Morong, I893.

The greatest contribution to the literature on the North American species of Potamogeton is by Thomas Morong in his Naiadaceæ of North Anerica, a monograph which includes 37 North Anerican species, It of which are confined to this country. Many of these species were studied througl succes$86309^{\circ}-15-2$ 
sive seasons of the year and a considerable body of knowledge pertaining to the development of the plants was accumulated. It is recorded that 7 of the described species are propagated vegetatively by one or more of the following structures: Rootstocks, tubers, winter buds, and stems.

SATVAGEAC, I894.

The work of Sauvageau is particularly a contribution to the liology of the Potamogetons. While there are additions in morphology and anatomy extending the observations of Irmiseh to other menbers of the genus, the most noteworthy investigations pertiin to the origin and the development of those vegetative structures which greatly facilitate the multiplieation of species during the vegetative period.

Sauvageau devotes a special memoir to P. crispus. He observed both forms of the so-called "burs" of this species, the slender spicular one and the more common dentieulate one, noting their origin, growth, and germination.

Lixperiments conducted in aquaria show that detached fragments of stems of various forms as $P$. lucens, $P$. densus, $P$. perfaliatus, and $P$. crispus derelop roots, shoots, and buds, and that such detached parts of plants constitute a rapid means of propagation. Investigation of the growth habit of $P$. natans discloses a condition in marked contrast to the above-mentioned species. No special propagative bodies exist, but the species perpetuates itself by the continuance of the rhizome anchored in the mud, a rhizome which maintains itself through the winter rest period with the submersed shoots in various stages of growth.

Experiments on seed germination indicate a latent period of considerable variability. In $P$. crisfus germination occurs within a year; in $P$. natans in from three to four years.

FRYER, IgOO.

The first two installments of a fine quarto work, The Potamogetons of the British Isles, by Alfred Fryer, appeared in rgoo. The monograph includes the varying forms and states as well as the recognized species. with accompanying plates, by the artist, Robert Morgan, who has rejroduced the jlarts in color with singular beauty and accuracy. Unfortunately for science, the author's death occurred before this important work was finished.

Fryer had an intimate acquaintance with the Potanogetons and their habits. He grew many speeimens in tanks in his garden, watehing developments there and in their native haunts at different times of the year. He grew Potamogetons in order better to classify them, for he recognized the necessity of having a long series of specimens of the same form. "One set," as he says, "would contain a series of forms from lucens to heterophyllus without a single gap. This would slow the way in which two quite distinct species pass from one to the other without a missing link." As a result of these observations a long and valuable series of communications on the genus, under the title "Notes on Pondweeds," appeared in the Journal of Botany from $I 88_{3}$ to 1899.

BENNETT, ISSO-I914.

In the Journal of Rotany Mr. Arthur Bennett's "Notes on Pondweeds" have appeared regularly from I $\$ 80$ to the present time. Hu has become the acknowledged authority on the classification of the genus.

PIFTERS, 1902.

In a Contribution to the Biology of the Great Lakes, Mr. A. J. Pieters notes the distribution of aquatic plants, describes the forms occurring in cliverse situations, presents details of structure, and records various methods of vegetative reproduction. The Potamogetons, he observes, form a conspieuous feature of the aquatic vegctation, predominating, as a rule, in aquatic associations or flonrishing in isolated patches. P. hetcrophyllus, he says, exemplifies the latter condition in that it thrives in a surfbeaten sandbar, where its runners ramify in all directions among the stones and pebbles, and its roots penetrate the underlying clay. Details of structure which are figured for $P$. ancricanus suggest the special adaptation of a thin, broad-leaved form, whose leaves are submerged, for withstanding diminution of light and ralid motion of water. The so-called hibernacula, or winter buds, represent the more familiar forms of vegetative reproduction observed by the author.

Po.ND, I903.

Further contributions to the biological jiterature of aquatic plants have been made by R. H. Pond. Two papers are presented on this subject. In the first, The Biolngical Relation of Aquatic Plants to the 
Substratum, the author showed that rooted aquatics depend on the soil substratum for the supply of nitrates. In conducting the expcrimeuts various aquatic plants were used, among which were $P$. perfoliatus and $P$. obtusifolius. It was found that both of these plants are dependent on the soil substratum for optimum growth, though the cuttings which were employed behaved differently in manner of growth: $P$. perfoliatus showed an increase of growth through the development of new rhizomes; $P$. obtusifolins manifested it in a continuation of the branches already present. The behavior of $P$. perfoliatus is in accord with the observations of Sauvageau in his experiments on the propagation of Potamogetons by fragments of stems.

The second paper of the author. The Larger Aquatic Vegetation, to appear in Ward's American Fresh-water Biology, supplements the work of the first by additional observations, discussions, and generalizations. From his observations on the substratum of the larger aquatics it appears that they may be found growing on gravelly, sandy, or loamy soil, the loamy soil supporting the greatest variety of species. Direct experiments on this point, with the natural conditions reproduced as nearly as possible, bear out this observation. The author states, moreover, that the character of the soil is so important a factor that it is possible to predict the nature of the bottom from the species that are found growing in it. For example, "Among the islands of western Lake Erie Potamogeton heterophyllus is common on the reefs and pebbly shores, but it is not noticeable in the coves where a good soil substratum exists, and so prominent is it in the former places that its presence may be considered characteristic of the flora."

JEPSON, I905.

In a popular article in the Sunset Magazine for February, I905, Prof. W. L. Jepson has set forth the possibilities of the marshes as a feeding ground for ducks. He has taken as a concrete illustration the Suisun Marshes in California, marshes which abound in the fennel-leaved pondweed, P. pectinalus, and which afford natural feeding grounds for the various kinds of wild ducks, more particularly the canvasbacks. The canvasback and the broadbill, both diving ducks which visit these marshes, devour greedily the tubers that are developed in abundance on the rootstocks and upper portions of the stems of this Potamogeton in the autumn. It is claimed that these tubers give the fine nutty flavor to the canvasback at this season of the year. Other ducks, nondiving species, feed on the tender rootstocks and leafy stems which are brought to the surface in the feeding operations.

\section{Ascherson and Graebner, 1907 .}

Ascherson and Graebner have published the last important monograph on the group, the Potamogetonacex, in Das Pflanzenreich. In this work the whole number of the described species has reached 87. Of these North America has 38, 14 of which are exclusively American. The numerous forms and varietics that are listed, though some common ones are omitted, illustrate how difficult the problem of classifying the Potamogetons still remains. In addition to the literature on classification the authors have assembled much important data on the anatomy and morphology of the group from foreign sources not generally accessible. Under the caption, Überwinterungsformen und Vegetative Vermehrung bei Potamogeton, the following propagative structures are figured: The slender, spicular bur of $P$. crispus; the large denticulate bur of $P$. crispus; the tuberous thizome of $P$. lucens; the tubers of $P$. pectinatus; and the winter bud of $P$. obtusifolius. All except the first are reproductions of Irmisch's celebrated monograph.

MCATEE, igit.

In a bulletin of the Biological Survey entitled Three Important Wild Duck Foods, Mr. McAtec lias assembled for Government publication important data regarding these foods, in the hope that they may become more widely known and propagated for the preservation of wild ducks. Analyses of the food content in the stomachs of the more important species of the game ducks show that the pondweeds, the Potamogetons, are a favorite plant food. The ducks which apparently show a special fondness for it are the canvasback, the redhead, the scaup, and others, tle first of which takes a very large proportion of the Potamogeton, the amount being nearly 50 per cent of the food eaten.

The best known duck food among the Potamogetons is $P$. peclinolus, of which the seeds, the tender rootstocks, and the tubers are eaten. It is general in distribution, thriving in iresh, brackish, or salt water. This and other widely distributed species are figured, and suggestions on how, when, and where to plant them are given. 
NICKLE, I9I2.

A Canadian bulletin, The Possibilities of Northern Ontario as a Breeding Ground for Ducks, by G. R. Nickle, is an investigation of the shoal waters of that Province with a view to their utilization for the propagation of wild game. In the preliminary survey the approximate amount of shoal waters is estimated to be $2,800,000$ acres, on which various edible water plants grow. But it is hoped that the natural supply may be augmented considerably by transplanting sucl of the larger aquatics as will contribute especially to the food of wild ducks. Among the valuable water plants suitable for transplanting, the author nanes several species of Potanogeton. $P$. natans, because of its abundant seed habit, $P$. perfoliatus and $P$. cristus because of their edible leaves.

Mickle AND ThoMpsox, IgI3.

A second Canadian bulletin by G. R. Mickle, written in collaboration with R. B. Thompson, supplements the work alrearly done in this line. A table giving the estimated percentages of the various constituents of duck food shows that both $P$. heterophyllus and $P$. perfoliatus form an important food constituent in the diet of wild ducks.

It will be seen from the foregoing résumé of the literature on the genus Potanogeton, that an important extension of the subject is in the field of biologic research, an aspect of the study which regards also the economic significance of the gronp. It is apparent, too, that this field of research concerns itself primarily with the propagation of Potamogeton by such structures as tend readily and effectually to distribute the group, viz, by burs, tubers, rootstocks, and winter buds. These have been deseribed gencrally in Furope and in America, and one may consider their production a natural phenomenon.

\section{SPECIES OF POTAMOGETON INVESTIGATED.}

The species which are included in this investigation have been selected from the more or less common forms growing in the lake's and ponds at Ithaca, $\mathcal{N}$. I., and vicinity (Spencer and North Fairhaven). And these species have been chosen because they offer variety in habitat and in methods of propagation, and beeause they serve an important róle in the economic relations of aquatic life, affording food, shelter, and support to many forms of animals which exist among them. 'The list of speeies follows:

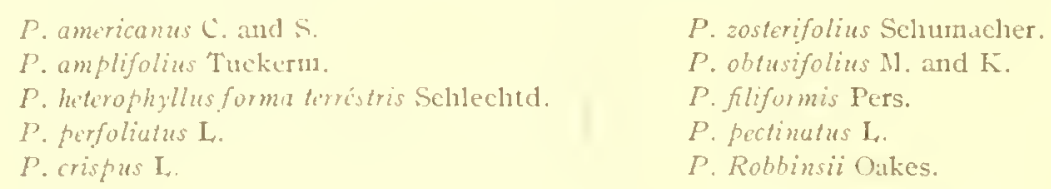

These Potamogetons were studied from September, 1912, to Jtme 1914, in their nattural habitats and in aquaria. Entire plants were thus observed throughout the period of development of those structures which are valuable in the vegetative propagation of the species. From time to time collections were made of entire plants with their subterranean systems intact. In shallow waters the plants were nprooted by hand, but in the deeper waters they were obtained by means of a rake or a grapple thrown over the side or the stern of a romboat. No collections were made in midwinter, i. e., from the latter part of December to the middle of February, when the frozen condition of the lakes and streams rendered it impracticable. P. crispus is an exception, since it was collected from spring pools at all times of the year.

These studies have afforded an opportunity to observe the animals that are intimately associated with the l'otamogetons. Such have been noted, especially those forms which depend upon these plants for food, support, or shelter. 


\title{
GENERAL SURVEY OF LIFE CONDITIONS OF THE SPECIES INVESTIGATED.
}

\author{
POTAMOGETON AMERICANUS.
}

This species, which has been grown from seed and cultivated through two suecessive seasons, will receive nore specific treatment later under the caption "Natural and artificial propagation." In its natural habitat this plant has been observed growing near the mouth of Fall Creek, a tributary of Lake Cayuga, and in a near-by cove of the lake, at varying depths of 3 to + feet. It has been observed also at Spencer Lake, at about the same depth but in much swifter water. In the latter situation the blades of the leaves are conspicuously attenuated. According to Fryer (1900), who has observed this plant in various localities, it is a plant of upland streams and rivers rather than of stagnant waters.

By uprooting the entire plant in the growing season, it is found that the stem springs from a rootstock that is deeply anchored in the mud, where new shoots radiate horizontally from the established parts of the plant. During the snimmer these young rootstocks produce large buds at their tips (fig. 6). After the plant dies down, which may occur as early as August, the subterranean system renains intact for several weeks. The new rootstocks, however, carrying the buds at the tips, become eventually detached through the disorganization of the parent stem and in time die away, leaving but little beyond the isolated buds to perpetuate the plant the following spring. Such buds, since they remain in a quiescent state during the winter, may be called winter buds or hibernacula, a term applied to structures of a sinilar nature and function. MIr. A. J. Pieters (I 901 ) doubtless referred to propagative structures of this kind when he recorded for $P$. americanus ( $P$. lonchites) "extensive rumers bearing buds at their ends," though no figures are given and no further observations are noted.

Fryer (1888) mentions an autumnal state of $P$. americanus ( $P$. Aluitans) in which the leaves are all narrowly linear or grasslike. These later growths, he says, are developed in the axils of old leaves during the natural decay of the lower part of the stem. They are ultimately set free as fascicles of narrow leaves which, after rootlets are formed at the base of the new growth, sink to the bottom and continue the life of the species. Such structures, which would be analogous to the winter buds of $P$. obtusifolius and $P$. zosterifolius, liave not been observed in $P$. americanus under investigation, though they may have been overlooked in the changes of water level during the autumn.

\section{POTAMOGETON AMPLIFOLIUS.}

This is an American species distributed quite generally throughout the continent. It forms large patches in the open vegetation but thrives also in close association with $P$. Robbinsii, Heteranthera dubia, Ceratophyllum demersum, Elodea canadensis, and other plants of aquatic meadows. As a forage plant it may be regarded as one of the best, growing continuously from early spring to late fall or early winter and producing an abundant herbage by reason of its numerous large leaves. The rankest growths have been found in the more quiet waters of Lake Cayuga and "The Pond" at North Fairhaven, at depths of 5 to 7 feet, in a substratum of mud rich in regetable mold. Propagation is rapid. The dense patches of stems, more or less unbranched, arise in great numbers from an intricately developed subterranean system (fig. 7). This 
extensive ramification of underground stems, richly provisioned with starch, remains more or less intact during the winter, earying at alternate nodes undeveloped shoots which quickly establish new extensions of the plant in the spring. Another means of vegetative propagation is found in the detached tips of branches which, after separation from the decaying parent stem in the fall or spring, sink to the bottom and become new centers of growth. New shoots also develop at the nodes of decaying stems and, on separation, sink to the bottom and take root as in the case of cictached tips and stems. Besides these vegetative neans of growth this P'otamogeton produces an abundance of seeds.

\section{POTANOGLTON HETISTOPHYLL'S.}

Varions forms of this species occur thronglout almost all of North America except the extreme nortl. One of the numerous forns, forma terristris Schlectd., is represented in this investigation and all data herein recorded pertain to this plant. It is a so-called land form of Potamogeton and brictly characterized in Gray, seventh edition, as "freely creeping in exsiccated places, producing numerous branches which bear tufts of oblong or oval coriaceons leaves but no fruit." This plant, which grows in the open air after being left entirely uncovered by water, has been observed in two places along the shores of lake Caynga-one in a railroad pool 2 miles east of Ludlowville and the other on a sandbar at lyyers Point. In cach of these places it is interesting to note that gradations in habit accompany the varying changes in habitat. The railroad pool is a particularly favorable spot for the growth of this I'otamogeton. It is an artificial pond which has been developed by building a railroad embanknent near the foot of the blulf bordering the lake. In consequence, a long, trongh-like depression exists between the bluff on one side and the railroad embankment on the other, with water from the lake seeping throngls and maintaining itseli at about the level of the lake. It is a situation especially favorable to the growtl of this plant, because the annual withdrawal of the water is gradtual, following the natural lowering of the lake level during the summer months. The bottom of the pool is covered with black mud, largely narl in composition, a foot or more in thickness, over which water may rise to the height of 12 to 16 inclues. During high-water level in the spring, this Potanogeton grows subnerged in the pond with its tuberous rootstalks anchored in the mud (fig. 8). Upon the withdrawal of the water, following the lowering of the lake level in the summer, drought conditions prevail, and then the submerged leafy stems give place to the land forms. Upon the approach of drought conditions the previously submerged leaves die and from the main rootstock or from those arising from the axils of the lower leaves (upper in some eases, Bennett, 1880) runners extend horizontally to a depth of 2 to 6 inches below the surface of the mud. From the fertile nodes of these rumners erect axes arise, bearing tufts or rosettes of leaves which cover the ground in great numbers and compete with mosses and small forms of sedges, carpeting the surface of the mud. The leaves of the rosette (fig. 12) are unlike the elongated, membranous, submerged ones. They are more rounded in form and coriaceous in texture, and by the presence of stomates on the upper surface of the lamina, they are enabled to function as ordinary leaves. 
During the season of 1913 the plants which flourished in a submerged condition during the month of May gradually changed their labitat upon the withdrawal of the water during June and becane land forms by the first of July. At this time the tuberous rootstocks which perpetuate the plant regetatively were well dereloped, and waited only the final stages in the curing process to becone the perfected regetative structures whicl tide this species over the unfavorable season of growth.

On the sand bar at Myers Point, the other station where this Potamogeton thrives, the life conditions are not so sharply marked by the complete withdrawal of the water during the dry season, and the various stages exhibited in the transmutation from aquatic to land forms were casily observed. In water about 10 inches deep the continuously submerged plants developed low bushy sten1s, with a few coriaceous leaves at the top. In shallower water the plants behaved in the same way, producing bushy, stuntedlooking stems, which finally graded into land form with leaves in tufts or rosettes resting on the exposed surface of the sand bar. The rootstocks, which were twisted and contorted in their effort to become established in the pebbly and gravelly sand bar, were buried from 2 to 4 inclies beneath the surface in the rich, black soil of the bar. All of the internodes of these subterranean stenis were more or less thickenerl and often attained a length of $S$ to 14 inches.

No fruiting plants were found, and this observation is in accordance with the generally accepted opinion that this form of heterophyllus is propagated entirely by regetative means. Observations on the artificial propagation of this species are recorded in a later chapter of this paper.

\section{POTAMOGETON PERFOLIATUS.}

The leaves of this plant afford valuable forage material, though the season of growth is comparatively short, the plants appearing late in the spring and dying quite early in the autumn. In the environs of Ithaca this species flourishes in quiet waters either in a substratumn of sand at the relatively shatlow depths of 2 to 3 feet, or in "aquatic neadows" in a substratum of mud at depths of 3 to 5 feet. The observations of Pieters (1901), in "The Plants of Lake Clair," and of Thompson (1897), in "The Biological Examination of Lake Michigan" extend the range of depth at which this species exists to 12 feet. During the growing season the vigorous undergronnd stems increase rapidly the output of forage material, since a single subteranean system produces a large number of erect, much branched, leafy stems. The experiments of Pond (1903) and Sauvageau (189.4) and the obserations of R. B. Thompson (1913) afford evidence of other means whereby the rapid extension of this plant takes place. In accordance with their observations, young branches, which are easily detachable, float away and rapidly become new centers of growth. In winter the vigorous and abundant subterranean system decays, leaving only the terminal shoots of two or three nodes (Fryer, 1900) to continue the plant the following spring. This plant, therefore, has three inportant means of vegetative propagation: By readily detached leafy stems, and by extensions of the subterranean system, both of which operate to multiply the plants during the growing season; and by the terminal portions of rootstocks which, remaining in a quiescent state during the winter, establish new plants in the spring. 
POTAHOOETUN CRISPLS.

This species, a native of Europe, was recorded in this country by Pursh as early as 1814 (Arthur Bennett, 1901). Since that time it has become established over an extensive area because of the remarkable facility for multiplying itself vegetatively. It is the most abundant Potamogeton in the ricinity of Ithaea, where it flourishes in various habitats-in deep or shallow water, in sand or mud bottoms, and in stagnant pools or flowing streams. It is singularly adaptive in each situation. It has been collected with $P$. pectinatus growing at depths of $S$ feet, in which habitat the internodes are extremely elongate; it has becn found in pools where the substratum is an accumulation of débris from ash heaps and dumping grounds; and it is not uncommon in the swifter parts of streams and along the lake shore in sandy situations where the substratum is thrown into ripples by wave and current action. In the latter situation it has always possessed short, stocky stems and a greneral dwarfish appearance.

$P$. crispus grows the year round and spreads with great rapidity. It is propagated primarily by "burs," peculiarly distinctive structures to which there is nothing quite comparable in our native species. Morphologically they are branches, but in the stage most frequently seen they are scareely recognizable as such nembers of the plant structure. They have a horny look and a reddish color. "The shortened internodes and thickened persistent leaf bases combine to give the characteristic bur-like appearance (fig. 22).

POTAMUGETUN ZUSTERIFOI,ICS

This flat, grass-like species of I'otanogeton is not largely foraged 11 pon by aquatic herbivores, yet it appears in greater or less abundance in most ponds and lakes and doubtless serves an inportant rôle in the economy of life by furnishing support and shelter to the countless small forms which have been found upon it.

$P$. zostcrifolius is anong the earliest of the Potamogetons to appear in the spring, as well as among the first of them to disappear in the autmmu. It flourishes in a substratum of mud in still or rumning waters, and while it is not adapted to possess the soil so completely as $P$. crispus, nevertheless it has effective means of perpetuatiug itself. Mr. A. J. Pieters (I901) remarks that this species, which he has observed growing in abundance in Lake Erie, may be losing the power to produce seeds. Indeed, during the past season few plants matured seeds in the several regions where they were observed, but all developed winter buds in great abundance (fig. 3.3).

Large quantities of regetation, that is, the accumulation of the raried and abundant mass that still exists in the autumn, have been hatled up to the surface for examination, and it was both surprising and astonishing to see the vast number of winter buds of this Potamogeton that were entangled among the stems of other plants. It suggests to an extent how well this species accommodates itself to its surroundings. It never forms dense patches of growth, but it often oceurs with aquatic plants that form them more or less densely. By rirtue of its slender, grasslike habit, it oceupies the interstices of the more rank aquatic flora, and it occupies these spaces as simple individual plants, not as erect axes of a complete and intricate subterranean system. The plants are anchored to the substratum by the roots only, which develop from the winter bud, and becanse of this loose hold in the soil they are readily pulled up. The large number of 
plants which have been uprooted appeared always to possess a comparatively simple, erect stem which developed from a winter bud without the ranifications of rootstock which are characteristic of other species of Potamogeton not grasslike in habit.

POTAMOGETON OBTUSIFOLILS.

This species is apparently an inportant aquatic forage plant, for its delicate leaves show abundant evidence of larval depredations throughout the growing season. It is somewhat grasslike, yet less stiff and harsh than the preceding species. It is a rare Potamogeton in the flora and has been observed in one place only, Spencer Lake, where it is found in a muddy substratum in shallow waters of more or less swiftness. The plant has a bushy habit of growth, branching widely toward the summit, a habit which tends to produce clense patches of these plants. At one place in the station it grows in such dense masses as to choke up the mouth of a small stream entering the lake.

The plants are late in appearing among the other aquatic forms in the spring, lagging behind $P$. zosterifolius a month or more. The bushy habit of the plant begins to show itself carly in the summer, when branches arising near the base of the plant ramify toward the top until the characteristic bushy habit is attained. Fruit is produced abundantly, but doubtless an equally important structure in the reproduction and distribution of the species is to be found in the large winter buds. These appear on the much-branched stems in great numbers and differ in no essential respect from those of $P$. zosterifolius except that they are much less stiff. As in the above-mentioned species, they fall away from the parent plant when mature and sink to the bottom. Iike $P$. zostcrifolius, too, there is characteristic simplicity in the underground system. The mature plants which have been collected show no tendency to produce ramifications in the substratum, nor any indication of a perennial habit, but the plants become readily propagated vegetatively by means of winter buds or hibernacula.

POTAMOGETON FILIFORMIS.

A habit sketch of this plant is shown in figure 36 . Morong ( 1893 ) states that this is a rare species in the United States. One collection only was obtained. The specimens were found early in July near Canoga on Iake Cayuga, where the plant flourished in shallow water and among calcareous rocks along the shore. The plants were short and bushy in habit and bore abundant fruit. In all cases the ercet axes developed from a tuberous rootstock which, judging from the numerous crect shoots that grew therefrom, is the common method of vegetative propagation in this species. The tubers (fig. 37 ) occurred in series of 3 to 5 on the rootstock. Although no opportunity was afforded for studying this plant during the successive seasons, it is deemed worth while to record the observations of one collection of plants, since this species of Potamogeton is unique in its habitat and promising in the possibility of seed and tuber production.

POTAXIOGETON PECTINATES.

This species possesses many inportant characteristics which reconmend it to the culturist of aquatic plants. It is one of the most abundant and widespread of the Potamogetons. P. pectinatus is regularly found in quiet waters, though it has a variable habitat in other respects, occurring in a substratum that is sandy or muddy and in waters $86309^{\circ}-15-3$ 
that are deep or shallow, fresh, salt, or brackish. It is also extremely variable in growth habit. Two of its renarkable forms which occur in Lake Cayuga and its environs and which Dudley (1886) describes as a slender form ${ }^{a}$ and a gigant ic form ${ }^{b}$ are included in the present investigation of this species.

$P$. pectinatus, the species which is common everywhere, is anong the first of the Potamogetons to spront in the spring, making its appearance early in April. Of such plants which appeared early in the season, over a hundred individual specinens were uprooted to determine the agent of propagation. In all cases these plants dereloped from tubers which were buried in the mud or sand. Figure 38 shows the general habit of growth from these reprodnctive structures. The new plant quickly establishes itself by developing simnltaneously with shoot formation an extensive subterranean system of stems, which in turn send up leafy shoots in great numbers. By this ramification of the underground stems, $P$. pectinatus eneroaches upon the soil so effectively as to produce dense patches of growth, to the exclusion, in some cases, of other species of aquatics. The plants bear fruit more or less abundantly, but, in general, tuber formation doubtless equals or surpasses seed production.

Tubers of various size occur, the size being dependent, more or less, on the nature of the enviromment. The largest and finest specimens were found at North Fairhaven in the quiet waters of Sterling Creek, where P. pectinatus forms a part of an equatic meadow renowned for its luxuriance of vegetation. These large tuber-bearing plants grow in the rich, mucky substratum at a depth of 6 to 10 feet in association with Elodea canadensis, Myriophyllum spicatum, Ceratophyllum demersum, L'triculuria rulguris var. Americana, Nymphea adiena and ot her Potamogetons, such as amplifolius and zosterifolizs. In this situation the plants are rapidly propagated from the tubers. On June 2i several specimens were collected which illustrate the complete cycle of tuber formation. Plants retained intact the old tubers, the new shoot-a tall, leafy, erect axis bearing in some cases a floral spike-and the new rootstocks bearing tubers. On many plants in this most favorable enviromment the tubers were greatly in exeess of the matured fruits, and often the only reproductive structures. The plant dies down early in autumn. In October attempts were made to collect underground stems to determine, if possible, a perennial habit in this region. Only portions of the rootstock were secured, but in erery instance disorganization had progressed to a considerable extent. The appearance of the tuber in the spring, when many of the plants were uprooted and observed with shoots growing from them, indicates a complete and natural separation from the parent stem, probably in the autumn. It may be inferred, then, that the tubers are the only vegetative structures that do survive the unfavorable growing season.

The slender form described by Dudley (1856) was found still occupying the same region in Cayuga Lake where it was abserved by him many years ago. The plants

a 100 - var. - ( (?) with slender elongated stems ( $\mathrm{I}$ to $x^{2}$ imeters), nodes remote, as are the whorls of the spike, whose peduncle is usudly over one-tourth meter long. Leaves few and slender, plants sometimes proliferous, Neat the lighthouse, Cayuga L. Dr. Rubbins "found no parallel for this remarkable form," in his own observations. Tusley: Willian R: The Cayuga Flora. Bull. Cormell Univ. (Science). p. 10\%.

D 1008. var. - (?) a gigantic form growing in deep water nortlwest and northeast of the lighthouse, Cay.tiga $\mathbf{L}$. Nut y.et found in flower or fruit, though examined more or lessfrequently during to years past. It is frequently proliferous, especially if detached. It grows in banks, the plumelike bushy tops reaching the surface of the water. The leaves and sheaths are similar to $P$. pectmatus, except in length. Dr. Robbins remarked that he had "nothing that comes ntar to it in length of ieaves-usque ad

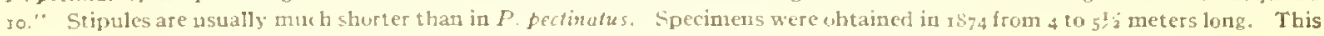
form was also noticed by Mr. H B. Lord, probably sumewhat earlier than I8;4. Loc. cit. 
grew in banks in sand and silt bottoms at a depth of 5 to 7 feet. They were quite unmixed with other aquatics. In July and early August the long heavily fruited spikes floated in dense masses at the surface and gave to these areas of the water a characteristic brown look. Proliferations were not found on these plants during the summer; fruits, however, were more abundant than on any other form of pectinatus.

The gigantic form of pectinatus grows in deep water. Plants 8 feet long are common, although many average but 5 feet at the end of the growing season. This form grows in a substratum of sand and silt at depths varying from 6 to 12 feet in a region of the lake exposed to a more or less constant sweep of the wind. The plants, therefore, which grow practically to the surface of the water, are subjected at times to vigorous wave action. Altogether these environmental conditions favor a growth of remarkable luxuriance. The plants grow in banks, and so thickly as to preclude the possibility of encroachment by other forms of vegetation, though in shallow places, where the growth becomes sparser, a few scattered representatives of $P$. crispus, $P$. perfoliatus, and Heteranthera dubia occur.

This form of pectinatus begins growth early in the spring. In May, I9I3, the plants already approached the surface of the water. On June 21, 1913, a plant bearing a single floral spike was found, although in several collections made thereafter neither flower nor fruit was obtained. This appears to be the first record of a floral spike on this form of pectinatus. From the collections made in November a few tubers were found on the tips of the foliage sprays of the plants that were uprooted from their natural moorings, although they were found more commonly on sprays that were floating in the drift. This latter observation is an agreement with Dudley (1886), who observed and described this form in Lake Cayuga. No rootstocks were secured, since attempts to uproot the plants at such depths with a grapple resulted always in breaking the stem just short of the subterranean system. This appeared to be embedded firmly and deeply in the substratum, at least more deeply than the length of the grapple teeth, which measured + inches. However, the bases of the erect stems, the parts which develop just above the rootstocks, possessed remarkable examples of proliferation. Thickened runners, more or less contorted, arose from leaf axils at the bases of the erect stems (fig. 50, A), terminated by large, elongate tubers. The bases of the stems were hard and woody, more especially so in the regions where they becane detached from the underground system. This condition suggests a continuation of the woody structure in the subterranean parts. It may be inferred perhaps, from the general habit of the plant and the attendant conditions of growth, that the rootstocks are perennial, and that the basal runners, which bear in abundance large tubers and green shoots, are the chief propagative structures of this form of pectinatus.

POTANOGETON ROHBINSII.

Although this Potamogeton is less well known than the other species, it is destined to be regarded as an important aquatic forage plant, first, because it is very prolific, and, second, because the foliage is very generally eaten. The habitat of this species, where it has been under observation, is not unlike that of $P$. amplifolius, with which it is of ten found in association. It has been observed in the quiet waters of lakes and ponds at depths of 3 to 5 feet in a substratum of rich, black mud. The stems ascend from a somewhat creeping base and branch profusely in a nore or less two- 
ranked arrangement, forming large, broad, flat sprays of foliage, which often cover the bottom in large patches. It is the rarest of all Potamogetons to frtit, at least in the situations where it was observed, but because of the tendency to branch profusely propagation is readily effected. The branches, especially those whose internodes remain short, become thickened and hardened through the storage of starch, and when detached function as propagative structures. This enlargement and induration may occur also at various points along the main axis that bears the propagative branches, so that the final dismemberment of the whole plant provides enormous possibilities in the multiplication of the species. Dismemberment may occur in the autumn, but the plant is hardy, and this natural separation of parts may be deferred till spring, then long rootlets develop at the nodes and establish the plant at once. The plant is tardy in beginting its growth in the spring, but this tardiness in growth is obviously advantageous to a plant tiat propagates mainly by vegetative means in the manner of this species. Horeover, a very material advantage accrues in that the full and complete foliage of this Potanogeton appears late in the season when many other aquatics, including Potamogetons, show sigus of decay. Growth occurs during the winter. It is not great, however, and manifests itself only in a slight elongation of the branches, producing fresh, green tips of foliage, which are foraged upon by aquatic herbivores almost as fast as the leaves appear.

\section{SUMMARY OF CULTURAL FEATURES.}

The Potamogetons which yield important forage products fall into two groups: Those which produce abundant herbage in their leaves- $P$. americanus, amplifolius, perfoliatus, crispus, and Robbinsii-and those which develop a large supply of starchy food products in the tubers and tuberous rootstocks- $P$. pectinatus, filiformis, and heterophyllus.

The species which grow best in the currents of streams are $P$. americanus and obtusifolius; in deep water, $P$. pectinutus, especially the slender and gigantic forms of Dudley; in calcareous regions, P. hitirophyllus and filiforinis; in exsiccated places, P. hetcrophyllus.

The species appearing early in the spring are $P$. americanus, zosterifolius, pcctinatus, hcterophyllus, crispus, and amplifolius; those growing late in the autumn and continuing throughout the winter are P. crispus, amplifolius, and Robbinsii.

Abundant fruit is produced in $P$. perfoliatus, obtusifolius, and filiformis, and on pectinatus in most situations. Vegetative reproduction occurs freely in all species. The important vegetative strnctures are: Winter buds or hibernacula in P. obtusifolius and zosterifolius; molified branches in $P$. crispus and Robbinsii; tubers in $P$. pecti. natus and filiformis; tuberous rootstocks in $P$. heterophyllus, and subterranean buds in $P$. americames, amplifolins, and perfoliatus.

\section{NATURAL AND ARTIFICIAL PROPAGATION.}

The natural propagation of Potamogetons has been touched upon in a general survey of life conditions, and it has been seen that these plants propagate freely by means of various vegetative structures. At this point it is desirable to consider this method of propagation in greater detail, and to present data which will afford a means of conparison between the general seed habit and the tendency to produce vegetative propagative structures. 
PROPAGATION BY TUBERS.

A conspicuous method of regetative propagation is seen in the derelopment of plants from tubers in $P$. pecinatus and $P$. filiformis. The tuber-forming habit of pectinatus has been described by Irmisch (1858), who earefully worked out the morphological details of the tubers in terms of the ordinary stem structure. His figures illustrate the development of tubers on detached parts of leafy stems, on the erect axis, and on the underground stems. It is not clear from which forms of pectinatus these drawings were made. In general, however, they bear a close resemblance to our most common representative of pectinatus, though no hint of the variability in this species is given beyond the fact that some plants were collected in deep water, and that the tubers were varied in shape, some being more cylindrical than others.

The work of Sauvageau (1894) confirms the observations of 1 rmisch as regards the tuber-forming habits of pectinatus, but this investigator also makes no allusion to the remarkable forms that exist in this species. His drawings, moreover, are, as he states, modifications of those by Irmisch. Both of these workers in this field recorded the time of tuber formation to be in the autumn. Jepson (1905) suggests an earlier development for those on the rootstock and the erect stem. He says: "The slender threads wlich develop one, two, and even three tubers at the end, are not only borne on the horizontal rootstocks and on the soil at the bottom of the ponds, but are also produced on the upright stems, and at the end of the season on the uppermost leafy portion."

Regarding the presence of tubers on rootstock, stem, and spray, the present investigation is confirmatory. Tubers have of ten been observed on all these parts of the plants. Additional figures and observations relate more especially to the season in which they occur and to their artificial propagation. Collections of plants made on the $15^{\text {th }}$ of May, 1913 , and thereafter throughont the growing season, show the presence of tubers in great numbers on the proliferating shoots of the rootstocks. Many of these tubers are well grown in May, though others subsequently arise on the extensions of the subterranean system which develop after this time.

Figure 41 represents the basal part of a small immature plant of $P$. pectinatus collected in shallow water June 20, 1913. Many plants at this time were more nearly mature and bore larger tubers, but it seemed desirable for illustration to select a small plant because in such all parts may be preserved intact during the collection of material, a task that is attended with considerable difficulty when the plant has attained a large size and great complexity of parts, especially in the subterranean region, where the underground stems are exceedingly brittle and tender. This figure (fig. $4 \mathrm{I}$ ) illustrates the general sequence of growth in what may be termed the typical vegetative life cycle of the plant. The order of development is as follows: The production of a leafy, erect shoot (C) from the tuber of the preceding season (A); the growth of the horizontal axis or rootstock (D); and the production of the stolon-like branch or runner which in turn bears a tuber or tubers at the end $(B)$.

As the season progresses the tubers become solidly packed with starch in sufficient anount, apparently, to bring the plants developed from them to a very advanced stage of growth, at least to render then quite independent of the soil for a considerable length of time. Figure 45, B illustrates the typical condition in this respect when tubers suspended in aquaria without contact with the substratum produce the future propagative structure. Thus the continued dependence of the plant upon the stored starch in 
the tuber would seem to be adrantageous, especially if growth oceurred under untoward conditions.

The tubers, hardened by the great quantity of starch that is packed into the tissues, normally pass through the winter in a dormant state. This, however, is quite easily disturbed, and by supplying continuously ordinary room temperatures the tubers may send forth shoots as early as October. Figure 45 , noted above, illustrates such a response to growth conditions, the plant having been developed between the dates of October 22 and December 20.

The propagation of tubers in aquaria has shown that when tubers occur in twos, for example, figure $4^{\circ}$, the larger one develops the sloot. The smaller one has never been seen to sprout unless by chance it became detached. In that case it developed an individual plant. It has been frequently observed that plants of this species when propagated in aquaria never attain their full size or vigor when deprived of a soil substratum, an observation that is in accord with the results of Pond's (1903) experiments on rooted aquatic plants.

The remarkable versatility of $P$. pectinatus as regards the origin of tuber-bearing runners has been clearly shown by Irmisch (I 858 ). There is, moreover, in each of these situations, on rootstock, stem, and spray, a considerable variation in size and number of tubers. For example, an underground stem or rootstock nay devclop then at the ends of slender, stolon-like branches which arise from the axils of fertile nodes as shown in figure 43. These have been found singly or in pairs, large or small, depending upon the richness of the substratum and the size of the plant. Again, the rootstock itself may be terminated by tubers which occur singly, in pairs (fig. 42), or in threes (fig. 39). Plants bearing rootstocks of this character have been collected at varions times during the growing season, and from each collection the specimens have shown comparatively short underground stems withont other tuber-hearing structures. Some rootstocks have shown no tendency to produce tuber-bearing runners or tubers at the end of the horizontal axis, but send up a succession of leafy shoots from the fertile nodes. It is suspected, however, that had such plants been undisturbed tubers night have developed, especially since at the base of these upright shoots there was always a bud, either latent or showing a tardy development.

In autumin pectinatus develops tubers on the leafy spray. They are generally snaller than those which occur on the rootstock, but quite conspicuous because of their pale, yellow color. They are borne singly or in pairs at the ends of runners that are briglit green and stouter than the stens from which the! arise (fig. 44, B, C). These structures are readily distinguishable about the time the plant begins to show signs of decay. They may occur on attached or detached parts of the plant. The remarkable prolificity of these sprays is a characteristic of this species. Repeatedly detached parts of the leafy spray have been placed in aquaria and tubers have been developed in abundance until the spray became completely disorganized. It is interesting to note that when this species grows in the currents of the strean the tendency to form proliferations on the leafy spray is conspicuously lessened, although portions of these plants when caught in the drift and carried to quiet water readily produce them in the new environment.

For the most part tubers are more numerous on sprays devoid of fruiting spikes, although exceptions are frequent. In examples of this kind, figure $4+, \mathrm{B}, \mathrm{C}$, shows the 
origin of tube-bearing structures, one arising near the base of the peduncle, the other solitary from the axil of a leaf. Figure 44, A, is a detail of such a spray showing the usual elaracter of the runner. Runners arise also on the lower parts of the stem (Irmisch, 1858). These, like many on the tips of the spray, may develop so late in the autumn that tubers never nature. What their fate is during the winter can only be conjectured. It is a fact, however, that when placed in aquaria they continue to grow slowly and eventually produce small tubers, or remain for a time in a quiescent state and then send forth leaves and other runners.

In the gigantic form of pectinutus (Dudley, 1886 ) the tubers are elongate and large in size. They are born on runners at the bases of the stems just above the substrat um of mud, and are therefore several feet beneath the surface of the water. Figure $6 \mathrm{r}$ shows the entire leafy axis with a tuberous runner attached at the base of the stem. This is the normal position for what appears to be the chief propagative structure of this form of pcctinatus, and the usual condition at the approach of winter. The runner is seen in detail in figure 50. The tubers are yellowish in color, and when stripped of seales, which envelop them at this season, appear as in figure 51. The remainder of the runner is dark green in color, more or less contorted and tuberous, and hardened throughont by storage of starch (fig. $50, \mathrm{~B}$ ). Secondary runners bearing tubers (fig. 50 , 1,2 ) are additional features in what withal is a remarkable propagative structure. Peculiar tuberous internodes, transition stages, perhaps, in the formation of tubers, appear frequenty and characterize the more hardened and resistant portions exclusive of the terminal tubers (fig. 52). On germination a leafy shoot and runner are produced. Figure 55, an illustration of a sinilar feature repeated in a series, was developed in an aquarium from the temninal tuber of a small runner. It illustrates how resourceful in the propagation of this species so small a structure nay become.

Young, green, leafy shoots arise irom the fertile nodes of the runner (fig. 50, D) and doubtless function in perfecting the propagative struetures of this persistent part of the plant, for at this time-that is, in the autumn-the leaves of the main axis begin to disorganize. The young shoots retain their greenness through the winter, remaining in a quiescent state meanwhile, and produce the main axis of the new plant the following spring. When these structures are transferred to aquaria, they pass through a winter-rest period, a period which is less easily disturbed, however, in this form of pectinatus than in others of the same species. Extreme plasticity is characteristic of various portions of the runner. Fertile nodes produce either tubers direet, or leafy tips, or runners, any one of which nna in turn produce a runner. The tip of a secondary runner may produce a leafy shoot (fig. 53), and a tuber, instead of elongating its axis in the natural way, may develop precociously a reserve bud which produces the leafy stolon (fig. 5t).

As in pectinatus generally, the detached sprays of the gigantic form show a greater tendency to produce tubers than the attached ones. Likewise the runner is the inlportant structure which bears them. Such tubers may become very numerous. As many as 15 hare been counted on a single plant (fig. 62). Detached portions of the plant bearing tubers float away in the drift, from whence they may or may not find a farorable place of growth in the spring. The tuber-bearing rumers developed at the bases of the stems rarely becone loosened from the tangle of vegetation at the bottom and nust therefore repopulate the area year after year, encroaching but slowly on the surrounding region. 
$P$. filiformis represents a tuber-forming species which produces these propagative structures apparently in the manner of $P$. pectinutus. Since material was collected but once during the summer, no definite data can be recorded regarding the details of tuber formation beyond the fact that the plants clevelop from tubers, as the collected materials show (fig. 36,37 ), and that these tubers, whether they oceur singly or in a series of two or more, have a likeness to those of pectinatus, in size resembling the conmon form and in shape approaching more nearly the deep-water form. In details of structure the tubers of fliformis are similar to those of pectinatus. Judging from the general habit of the plant it seems fair to assume that the tubers have arisen in the same way and that vegetative propagation would depend largely npon them.

PROPAGATION BY TLBEROES ROOTSTOCKS.

The regetative structures of $P$. heterophyllus teréstris are illustrated in figures 10 and II. Morphologically they are a series of more or less shortened and hardened internodes richly provisioned with starch. They are borne at the teminal portions of the underground stems. Well-developed buds, the incipient, erect axes, occur at alternate nodes of the strnetures, while the intervening noles remain sterile, as in the case of undifferentiated rootstocks. Figure 8 represents a typical plant collected early in May. At this season the plant is still submerged. The tuberous rootstock of the previous year sends up young, ereet shoots from the fertile nodes, aud extends the growth horizontally by an elongation of the terminal bud to form the new rootstock.

The underground stems acquire a distinetly tuberous appearance very early in the summer. At Irvers Point, where the collections were made frequently, the tuberous character became apparent at the time when clrought conditions began to prevail in the pools; that is, when the water level was reduced to such an extent that the submerged, leafy shoots gave place to the later-formed, erect shoots topped with tufts or rosettes of acrial leaves which rest 11 pon the nutud. Figure 12 represents a plant of this kind. By comparing the plants shown in figures 12 and 16 the origin of the tuberous rootstocks is elear. In figure 16 tuberous structures appear at the ends of the new undergronnd stems, B and C. This tendency to produce the tuberous growth may appear carly when the plant is still submerged, though it may le deferred till dronght conditions prevail, when the new type of leaves forning the rosette above the gromd function to produce the abundant storage of starch which is found in the nature tuberous rootstocks.

Some underground stems, thronghout the growing season, continue to produce internodes nontuberous in structure (fig. 9), but they are exceptional rather than the rule. The tip of the rootstock that is destined to become tuberous generally shows this character very early. The intemodes at the end clo not elongate in the usual way, but appear serially in a more or less bead-like form (fig. 10 and 11 ). Figures 13 and it represent the tuberous rootstocks partially devcloped. Figure 10 shows a fully mature one. These structures, and many others in similar stages of developtnent, were collected in $\mathrm{July}$ and it is interesting to note that while sonse are only approxinately mature others are fully so thus early in the season. In November all evidences of other plant parts have disappeared and the tuberous rootstocks only are left isolated in the innd, where they remain in a quiescent state through the winter. A typical structure, as it 
appears at the beginning of the winter, is seen in figure 11 , althongh variations in the length and thickness of internodes are not uncommon.

Tuberous rootstocks have been transferred to aquaria, where the growth has corresponded exactly with that exhibited in the natural habitat except in one respect, the development of aerial tufts of leaves. Bnt the explanation of this omission in the cycle of development is clear, since the plants remained submerged in the aquaria. The period of desiccation not having been interpolated, it is assumed that the tuber formation progressed in a natural manner for the species. Figures 16 and 17 , drawn from aquariun specimens, show how in the purely aquatic phase of its existence the natural labit of growth and reproduction in this Potamogeton is reproduced under artificial cultivation.

\section{PROPAGATION BI SLBBTERRANEA.Y STEMS NOT TLEBEROLS.}

Among the species studied, $P$. perioliatus, $P$. amplifolius, and $P$. americanus are propagated in this manner. The plants are carried over the winter by means of the terminal portions of underground stems, which are generally stouter than the ordinary ones and which bear conspicuous scaly buds. These buds are the incipient shoots from which the elaborate plant structures of the following season are developed. Sauvageau (IS9.4) has figured this propagative structure for $P$. perfoliatus as he found it at the approach of winter. He states that the entire plant dies in autumn, except a few internodes which bear the buds for the continuation of growth in the spring. In figure 18 is represented a portion of an underground stem that surrived the winter and produced the first few internodes of growth. The scales on the part that lasted through the year are distinctive in appearance. They are larger and looser than the ordinary ones, black in color, and leathery in texture (fig. IS, A.)

In $P$. amplifolius perennial parts are also found in the underground stem. Figure 7 represents the characteristic features of such a structure at the beginning of the winter. The young, erect shoots $A, A, A$, wit partially unfolded leaves at the tips, pass the winter unchanged and serve to promote rapid growth in the spring. The buds terminating the horizontal stems remain latent through the winter and on unfolding in the spring push out in all directions through the substratum. In these ramifications a subterranean system of interlocking stems and roots is dereloped that fixes the plant with exceeding firmness in the soil.

In $P$. americanus regetative propagation is accomplished by subterranean scaly buds which generally grow in pairs at the end of the rootstock (fig. 4 and 5). The general structure of the bud resembles that of $P$. perfoliatus. It is an incipient shoot, possessing a succession of very short internodes and young leaves, with scales surrounding the whole axis. A small portion of the rootstock generally remains attached to the buds and persists through the winter.

PROPAGATION LI WINTER WLDS.

The winter buds afford the only means of regetative propagation which have been observed for $P$. zosterifolius and $P$. obtusifolius. These structures derelop at the ends of the shoots. The terminal internodes remain short and, becoming completely corered by closely overlapping leares and stipules, form a hard, compact, cone-like bud. 
Such buds become conspicuous during the month of August. Later when they are mature they easily fall away from the parent axis, which thereafter dies down completely. Being heavier than water, the buds sink to the botton and by the middle of Octoher they have either disappeared or have become entangled in the accumulations of Elodea, Myriophyllum, Ceratophyllum, etc., which still remain intact. In the disorganization of this mass of vegetation, a gradual settling of the entangled buds takes place and they eventually find lodgment with the others in the substratum of mud, where they remain in a quiescent state till early spring. Such buds nay properly be called hibernacula, since they pass through the unfavorable winter season in a state of rest.

The general external aspect of the winter buds is seen in figures 33,63 , and 64 . In size and form the two buds are quite similar but the leaves of oblusifolius are less stiff and harsh. In the internal structure of the bud (fig. 34) the typical branch-like claracter is apparent with the young leaves closely crowded toward the tip.

Plants of both species have been reared in aquaria by anchoring the buds in sand or mud. The latter operation is not necessary, however, since mature buds sink nat urally to the bottom, but it was a precautionary measure against the disturbance of buds under observation in aquaria. The plants of zostcrifolius thus propagated did not bloom, but produced winter buds; those of obhusifolius bore flowers and fruit early in August.

During the winter the loose leares on the outside of the bud decay, but, on the whole, the entire bud is well preserved. This resistant character is more especially true of zosterifolius, in which many of the enveloping leaves of the bucl persist long after the new plant has become established. In the spring the first sign of growth is manifested by a spreading of the inclosing leaves. Then follows the development of roots from successive nodes (fig. 35) and the elongation of the internodes at the tip of the bud. This elongation carries the young leaves forward and upward, and in a slort time the general habit of the plant becomes apparent (fig. 65). The various stages in the growth of the bud in the spring are, in so far as they have been observed, similar in those two species of Potamogeton, cxcept that obtusifolius lags behind zosterifolius.

PRUPAGATION BY BURS

P. crispus is the single example of such vegetative propagation. The first evidence of propagative structures by means of which the growth of this species is rapidly extended became noticeable early in Nay. At that time the so-called "burs" (fig. 22) made their appearance. They were enormously abundant, appearing in the axils of nearly all the leaves. Many of them becane fully mature by the middle of the month, especially those which developed in pools of standing water where the daily temperature of the water was comparatively high. In the colder waters of spring pools and of the open lake these propagative structures, like the flowers and fruit, were retarded in developnent, maturing about two wecks later. As the summer advanced the development of the burs decreased until by the middle of July only scattered individuals were to be found.

As a rule, the burs occur in the axils of the leaves. They may, however, terminate the growth of the axis (fig. 30). In this latter position they may occur in pairs (Savaugeau 1894), often with a flowering spike. They may develop from the rootstock 
directly (fig. 3I), though this oceurs but seldom. On the maturity of the bur detachment from the parent stem is an easy and natural process. The tissue just below the pointed base of the bur becomes softened and the burs fall away, either by their own weight or by accidental contact with other objects. On reaching the botton, anchorage in the substratum is facilitated by the peculiar shape of the bur, a sharppointed, spindle-shaped structure that is heavier than water. A rest period oceurs before germination takes place. This rest period is apparently a varied one, depending on the season when the bur is matured. Those which maturect early in the season, in so far as it could be determinech, germinated in the fall, and in October bore shoots from 6 to ro inches long (fig. 59). Those maturing late passed the winter in the quiescent state and germinated early the following spring.

The slender, spicular burs (iig. 2I) described by Irmisch (i 858 ) and by Sauvagean (1894) were found more or less conmonly in the axils at the base of the ereet stem, and always few in number compared with the stouter form. It is interesting to note in this connection that these spicular burs appeared more abundantly on the so-called "state" of $P$. crispus, a plant with flat, not undulate leaves, said to be a young state of crispus (Fryer, i90o). In one of the spring pools from which collections were made the spicular buds predominated on what appeared to be matured plants of this flatleaved form. The plants were never so vigorous looking as those in the other situations, and the appearance of the spieular burs upon them may be explained by differences in habitat. Generally they appear to be poorly conditioned plants, and from observations on their development it would seem that they are a starved state of crispus rather than a young state.

The development of the large bur (fig. 22), which Sauvagean (IS94) deseribed in part, has been observed in the field and in aquaria throughout the various stages, from its beginning as a small branch to its completion as a mature bur. Since the steps in the formation are essentially the same under natural or artificial conditions, observations will be presented on the material under control in the laboratory.

Vigorous looking plants were collected in the latter part of March and anchored in a soil substratum in aquaria with rumning water. Cuttings also were used, some of which were anchored in the soil and others allowed to float on the surface of the water. Three weeks later, short, stunted-looking branches appeared in the axils (fig. 26, A). They exhibited at once a noticeable thickness of the axis and later the peculiar denticulate appearance at the base of the leaves (fig. 22, a). When the diameter of the branch had become considerably augmented and the denticulate margin conspicuous, disorganization of the leaves commeneed from the distal end and proceeded toward the base. Disorganization eeased at the tip of the denticulate base (fig. 22, $a, 1$ ). By this time the basal portion of the leaf was hardened, thickened, and horny like the axis, and the entire structure presented the characteristic burlike appearance. Figure 60 shows several small-sized denticulate burs in various stages of development.

Eissentially the two kinds of burs are similar, differing only in certain minor details. In the bur shown in figure 22 the leaf bases are large and always denticulate, the buds in the axils are relatively small, and the internodes are short. In the spicular bur (fig. 2 I) the opposite is true. The leaf bases are small and spinous with a smooth margin, the buds are well developed, and the intemodes are comparatively long. A difference 
between them is also apparent in the time of occurrence and in position on the stem. Imisch (1858) recognized a disparity between them and suggested a difference in origin, though he was not able to determine this for both forms. The spicular burs he found originating from the axillary buds of clecaying, floating stems in autumn. The denticulate ones he found always mature and cletached from the parent stem in muddy bottoms of pools. Sauvegeau (1894) describes and figures both forms of burs, giving their origin as well. My observations, however, are not in full agreement with their representation on the stem as expressed in Sawrageau's figures. According to his illustrations, both fornus are abundant on the same branch and at the same season of the year. This has not been found to be the established order in vigorons and healthylooking plants. Numerous collections of $P$ '. crispus indicate that when the denticulate burs are abundant-that is, in the early part of the growing season-the spicular burs are scarce, and if present on the same sten they are sparsely represented at the base of the axis. In every ease the large denticulate bur scems to be the produet of strong and vigorous-looking plants, and the spicular bur a result of poorly conditioned ones. That the spicular bur is a weakling would appear to be borne out by observations on their development. When grown in aquaria they have been found on sickly-looking plants and when gerninating burs have been deprived of their vigorously growing shoots, small shoots bearing spicular burs have replaced them. In this instance a disturbance of the natural trend of growth would be the occasion of their formation. When the spicular burs geminate they produce shoots bearing leaves not crisped, but narrow and flat (fig. 25).

The internal structure of the bur is fundamentally like that of the ordinary stem. No new features appear in the tissues of any part of the bur, but starch grains are present in such great quantities that the cells become distended with them. In the fully developed bur (fig. 71) the cells become so greatly cxpanded that the air cavities are practically obliterated. It is to these distended cells so compactly stored with starch that the hardened, indurated character is due.

The accunnlation of starch in the bur furnishes an abundant storage supply for rapid growth, after a rest period of greater or less protongation, depending upon the time of formation. Burs formed early in the summer may germinate early in the fall, or, like those of later development, pass the winter in a quiescent state. Figure 23 shows a stage of germination which is usual in the early spring. It is obvious from the general appearance of the shoots that burs of this character passed the early part of the winter in the resting stage. At the same time burs much more advanced in stage of growth (fig. 32) are frequent, and it is assumed that these are comparable to burs that germinated in the fall (fig. 59) and grew but little cluring the winter. In aquaria a variable rest period is common. Under these conditions burs have been germinated after periods of six weeks and of three months.

In the germination of a bur there are as many possibilities for the production of stems as there are axillary buds on it, although usually not all of the buds germinate. The greater number of burs bear but one shoot eventually, but several may begin growth and produce short shoots (fig. 23). By experiment it has been found that when a bur is broken into bits with one bud per node, each bud will produce a shoot. In the derelopment of a plant from the bur, progress in the growth of a shoot manifests 
itself first by the establishment of an erect axis, from which very soon a subterranean system arises in the manner shown in fignre 27. By further extensions of these axes the number of branches is greatly augmented and the capacity for multiplication greatly increased.

$P$. crispus, like most of the Potamogetons, propagates readily by detached stems. Many of these have been picked up in the drift along the lake shore where under favorable cireumstances some, doubtless, find lodgnent and establish new centers of growth. Besides, in the spring there have been found leafy axes which, while still remaining attached to the parent stem, lie prone upon the muddy or sandy substratum and, becoming rooted at the nodes, send up a long series of erect stems (fig. 20). In this manner $P$. crispus combines the rapid growth from stolons with the normal spread of the subterranean system and forms an effective means of possessing the soil.

The large number of burs which are developed indicate that they are the ehief source of distribution in this species. Some plants doubtless develop from seed, though they can not represent any great number of the whole since comparatively few seeds mature. To obtain some data on this point a large number of young plants were pulled up and to the most of them a bur was attached, an observation which shows that, for the region at least, this structure was the ehief agent of propagation. From the standpoint of prolificity, $P$. crispus represents a chesirable species for cultivation. It remains to be shown that this abundant herbage is of importance in the economy of aquatic life. Data relative to this are recorded under the heading "Economic aspects of Potamogetons."

PROPAGATION IY FRAGMINTS OF STEMS.

In $P$. Robbinsii the propagation occurs exelusively by vegetative means, depending upon a more or less complete dismemberment of the plant. This breaking of the plant into propagative structures does not take place at random, but oceurs at very definite points throughout the leaf-bearing part of the plant. At intervals along the axes of the stems, a few internodes develop which are very short, and in them starch is stored so abundantly that they becone hardened and stiff and noticeably thickened in diameter. At the limits of these indurated regions where the stems appear constricted, the tissues soften when the structures are mature, and dismemberment becomes a natural operation. The process of separation is similar to that which is met with in $P$. crispus and which causes the detachment of the bud from its parent stem. Besides the main axes of the plant which break up into many potential units, there are also numerous short, axillary branches which possess the characteristic feature of the propagative structure. The internodes are likewise short and stiff and conspicuously augmented by the deposition of starch. Moreover, they are always provided with a growing terninal bud, a feature which facilitates rapid propagation. When an axillary shoot becomes 6 or more inches long it behaves like the main axis of the stem eventually breaking up into several propagative structures. In figure 67 is represented a single branch showing the constricted appearance which distinguishes a stem bearing more than one propagative structure.

In the spring, often before a general dismemberment of the plant occurs, very long, white rootlets are developed at the nodes (fig. 57). These rootlets serve to anchor the new growth, whether it be an attached part of the plant or a seattered fragment of the sten. The provision for the initial growth in these fragments of stems lies in the storage 
of starch within the tissues. Starch is so abundant that the air carities are considerably reduced by the distension of the cells (fig. 71 ). In portions of the stem where the tissues are not obscured by the deposition of starch, it is seen (figs. 69.70) that mechanical tissue is scattered through the stem in greater abundance than is common in the other Potamogetons, serving to support the heary sprays of foliage and to give the rigidity of stem which is characteristic of this species.

In $P$. amplifolius the tip ends of the branches function as propagative structures in a manner similar to $P$. Kobbinsii (fig. 58). These structures appear in the autumn developing only at the tips of the branches. The internodes are short and thick and densely packed with starch. At the end there are a few partially unfolded leaves which continue to grow slowly or, at least, remain green all winter. These rapidly expand when the roots develop in the spring and the entire structure forms an effective and rapid means of propagation.

PROPAGATION LI SEEIS.

While the main purpose of this paper is a consideration of the vegetative means of propagation, yet it is important by way of comparison to present such data as are available on the propagation of these plants by seeds. In reviewing the literature on the seed germination of Potamogetons, it appears that Irmisch (1 $S_{5} 8$ ) and Sanvageat1 (1 894 ) have made the only contributions of importance. ${ }^{a}$ Irmisch figures the germinating seeds and two smalt seedlings of $P$. natans but otherwise gives no data concerning them. Sauvageau found that $P$. crispus, perfolutus, and pectinatus germinate in less than a year and that $P$. natans remains dormant thrce or more years. No figures accompany' his account of their behavior.

In the course of the present investigation additional observations have been made on $P$. pectinatus and $P$. americanus. The seeds of both species were gathered in October and kept in cold storage through the winter. On Jannary 24 seeds of each kind were placed in aquaria and kept at ordinary room temperatures. On February if, the seeds of pectinatus began to germinate, but this process was very irregular, extending over a period of three or more weeks. These seedlings lacked vigor and nothing came of them. On Narch i 5 other seeds of the same species were taken from cold storage and placed in aquaria as before. In this later planting germination was more uniform, the majority of seeds sprouting within a few days of each other. Subsequent growth was rafid and vigorous. It appears from the beharior of the seeds in the two experiments that the later planting is advantageous. Figures 46 and 47 represent seedlings of the second planting 3 and 5 days old, respectively. Figure 48 represents a seedling of the same species about 10 days old, and figure 49 , one about 3 weeks old.

The seeds of $P$. americanus planted on January 24 , showed no signs of life till May 5. Those of the second planting germinated between June 13 and 15 . In this species also the later planting proved to be more successful. Figures 2 and 3 represent seedlings, respectively, 5 and 14 days old. When the seedlings were abont 3 weeks old they were transplanted and kept in out door aquaria with running water till October. Figure 4 shows one of these seedlings which produced winter buds during the latter part of the growing season. These winter buds described in a preceding chapter are the vegetative

a In a recent publication by Esenbeck the secdlings of $P$. cologotus aredescribed. (E)senbeck, Emst: Beiträge zur biologie der gattungen Potamogeton und Scirpus. Flura, bd i. June, 1914, Fo. 151-212, fig. 59) 
propagative structures eharacteristic of the species. All of the scedlings produced them. Figure 5 represents the first shoot in a germinating winter bud. It may be assumed from the general behavior of the seedlings and the growth from the hibernacula that in this species vegetative structures only are matured the first year, and that seed formation is deferred at least until the second year.

At present definite knowledge regarding the young stages of Potamogeton, in general, is very meager and this is doubtless attributable to the fact that the plants are small and inconspicuous the first year and fail to develop fruit until one or more vegetative reproductions of the plant have taken place.

\section{PRODUCTION OF SEEDS AND VEGETATIVE PROPAGATIVE STRUCTURES.}

The abundance of $P$. crispus and $P$. pectinatus in the local flora have made it possible to observe the relative production of seeds and vegetative structures in a considerable number of these plants. Besides, the formation of the conspicuous vegetative structure in both species is practically synchronons with seed formation. The observations on mature plants selected at random form the basis of the following tables:

Tabulations of Propagative Strictures in Potamogeton crispus, June i6, igiz.

(A) BUR FORMIATION

\begin{tabular}{|c|c|c|c|c|}
\hline \multirow{3}{*}{$\begin{array}{l}\text { Number of } \\
\text { plants. }\end{array}$} & \multicolumn{3}{|c|}{ Denticulate burs. } & \multirow{3}{*}{$\begin{array}{l}\text { Spicular } \\
\text { burs, num } \\
\text { ber. }\end{array}$} \\
\hline & \multirow{2}{*}{$\begin{array}{l}\text { With burs } \\
\text { only, num- } \\
\text { ber. }\end{array}$} & \multicolumn{2}{|c|}{$\begin{array}{l}\text { Plants with both burs } \\
\text { aud foral spikes. }\end{array}$} & \\
\hline & & Burs. & $\begin{array}{l}\text { Floral } \\
\text { spikes. }\end{array}$ & \\
\hline 4 & I & $\cdots$ & $\cdots$ & $\ldots$ \\
\hline I & I & $\ldots$ & . & I \\
\hline 2 & .. & .. & I & $\ldots$ \\
\hline 4 & 2 & .. & . & .. \\
\hline$i$ & . & 2 & 2 & . \\
\hline 9 & 4 & $\therefore$ & $\cdots$ & $\cdots$ \\
\hline 2 & .. & 4 & $\cdots$ & 1 \\
\hline 3 & .. & 4 & 3 & .. \\
\hline I & . & . & 3 & $\cdots$ \\
\hline I & 5 & $\cdots$ & .. & 2 \\
\hline I & & 5 & 2 & I \\
\hline II & 6 & $\ddot{\sigma}$ & $\because$ & $\cdots$ \\
\hline 6 & $\because$ & 6 & $\mathbf{I}$ & $\because$ \\
\hline 6 & 3 & $\ddot{8}$ & $\because$ & I \\
\hline 3 & . & $\begin{array}{l}8 \\
8\end{array}$ & I & $\cdots$ \\
\hline 2 & $\because$ & $\begin{array}{l}8 \\
8\end{array}$ & 2 & $\cdots$ \\
\hline 1 & $\ddot{8}$ & .. & $\begin{array}{l}3 \\
. .\end{array}$ & $\cdots$ \\
\hline $\begin{array}{l}9 \\
2\end{array}$ & 9 & .. & $\because$ & $\ddot{i}$ \\
\hline I & 9 & . & . & 4 \\
\hline 2 & . & 9 & 2 & I \\
\hline 12 & .. & Io & . & .. \\
\hline I & . & 10 & I & . \\
\hline I & $\ldots$ & I0 & 2 & $\ldots$ \\
\hline$s$ & II & $\ldots$ & . & .. \\
\hline I & .. & II & 2 & 2 \\
\hline I & $\ldots$ & 12 & I & I \\
\hline 3 & 12 & .. & & 2 \\
\hline 1 & .. & I3 & 3 & .. \\
\hline I & 15 & & & \\
\hline I & .. & 15 & 2 & I \\
\hline I & 21 & $\therefore$ & 2 & a \\
\hline 100 & 111 & I35 & 32 & 20 \\
\hline
\end{tabular}


Tabulations of Propagative Structures in Potamogeton crispus, June i6, igr 3 -Continued.

(B) SEED FORMATION

\begin{tabular}{|c|c|c|c|c|c|c|}
\hline \multicolumn{3}{|c|}{ Plants bearing sterile spikes. } & \multicolumn{4}{|c|}{ Plants bearing fertile spikes. } \\
\hline $\begin{array}{l}\text { Number of } \\
\text { plants. }\end{array}$ & $\begin{array}{l}\text { Nimber of } \\
\text { spikes per } \\
\text { plant. }\end{array}$ & $\begin{array}{l}\text { Number of } \\
\text { llowers on } \\
\text { spike. }\end{array}$ & $\begin{array}{c}\text { Number of } \\
\text { plants. }\end{array}$ & $\begin{array}{c}\text { Number of } \\
\text { spikes per } \\
\text { plant. }\end{array}$ & $\begin{array}{l}\text { Number of } \\
\text { fertile } \\
\text { spikes per } \\
\text { plant. }\end{array}$ & $\begin{array}{l}\text { Number of } \\
\text { seeds set. }\end{array}$ \\
\hline 12 & 1 & $6-7$ & 4 & 1 & 1 & $2-4$ \\
\hline 10 & 2 & $4-7$ & 3 & 2 & I & $1-2$ \\
\hline 16 & 3 & $5-8$ & 0 & 3 & I & $1-5$ \\
\hline 6 & 4 & $s \rightarrow 9$ & 2 & 4 & I & $2-8$ \\
\hline 2 & 5 & $5-8$ & i & 0 & I & 2 \\
\hline 3 & 6 & $5-7$ & I & 2 & 2 & 6 \\
\hline 1 & 7 & $5 \div$ & r & 9 & i & i \\
\hline 50 & 139 & $\ldots$ & I8 & 53 & 19 & \\
\hline
\end{tabular}

Table A shows a preponderance of burs over floral spikes; table B, a preponderance of sterile spikes over fertile ones. A comparison of the tables A and B shows that bur formation exceeds seed production; that is, the important mode of increase is by vegetative means. It should be remembered in this connection, however, that the bur which is the most conspienous is but one of several vegetative structures contributing to the rapid extension of this species, and that seed production is, therefore, even less important relatively than the tables suggest it to be.

tabllation of Propagative Strictckes in Potamogeton pectinates, September 30 , igiz.

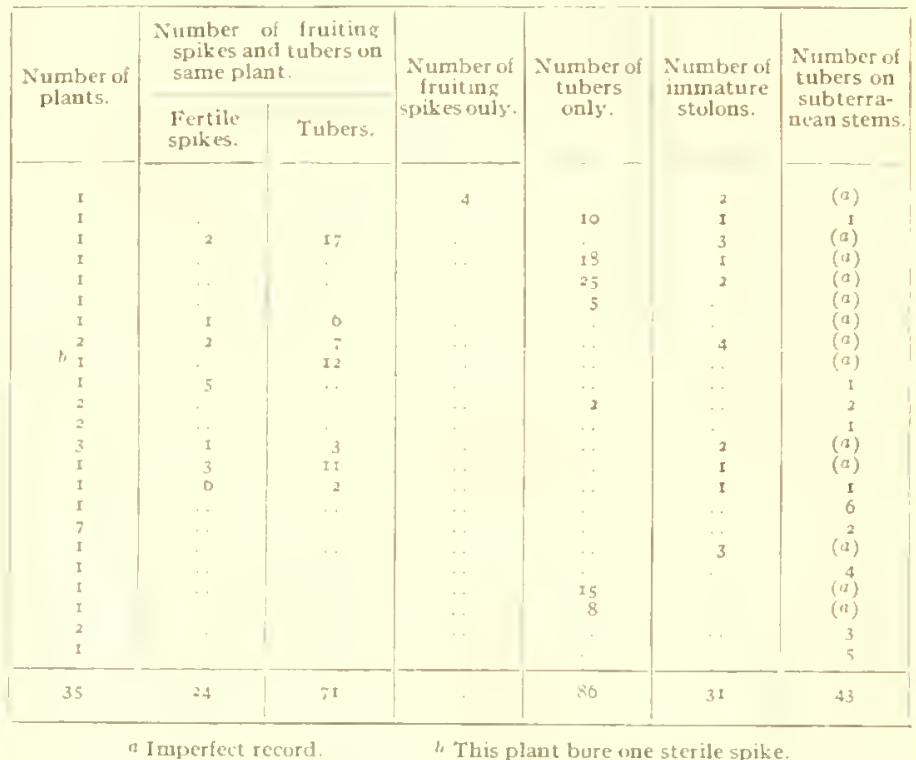

The fertile spikes of $P$. pectinalns produce, in general, from 10 to 15 seeds. The tubers occur singly, in pairs, and in threes. Dearing these possibilities in mind, the tabulation of $P$. pectinatus indicates a close approximation to equality in the production of seeds and tubers. The snall number of plants from which the data were collected is an objection which could be justly put forward, vet the results conform in general with field observations in restricted areas where the comnon form of pectinatus 
predominates. Propagation by tubers is, as we have seen, the more rapid method and the one which produces a lixuriant foliage early in the growing season.

In view of the observations and experiments, it is clear that in any project in which the propagation of Potamogetons is an important feature, success will be measured by adherence to the general principle that vegetative reproduction is the dominant mode of increase in the genus Potamogeton.

\section{ECONOMIC ASPECTS OF POTAMOGETONS.}

In the study of the various phenomena attending the propagation of Potamogetons opportunity was afforded to observe, more or less closely, various aquatic animals which abounded on these plants. Their presence in such great numbers suggested the possibility that the Potanogetons might play an important róle in the economy of life beyond that of mere shelter and support, or other mechanical and indirect relations which have been ascribed to the larger aquatic plants for many years.

It has been stated by Pond (1905) that-

The larger aquatic plants, as such, are, while living, little used as food by aquatic animals, yet they greatly increase the surface available for the attachment of microscopic plant forms, which are eaten by smaller animals, and the latter in turn by the fishes.

In the very recent publication by Shelford (1913), bearing on the life relations of aquatic animals, but little importance is attached to the larger aquatic plants beyond the various mechanical and indirect relations that have so long been attributed to them. He says:

The smaller aquatic animals are commonly either alga-eaters or predatory. The larger aquatic animals are commonly predatory or scavengers. The rooted vegetation is eaten only to a small extent. Small floating or swimming plants and animals are the basis of the food supply of larger animals. We could probably remove all the larger rooted plants and substitute something else of the same form and texture without greatly affecting the conditions of life in the water; that is, so far as the life habits of the animals are concerned. ** * Plants in water are of particular use to animals as clinging and nesting places.

Recent research bids fair to modify these generalizations by Shelford. Such a relation as Pond describes has frequently been observed in $P$. pectinatus in the autumn when myriads of midge (chironomid) cases have been found applied to the leaves (fig. 56). The leaves are not eaten but they are thickly covered with diatoms and other small algæ which, doubtless, afford foraging materials for the larvæ. A small caddis fly (hydroptilid) larva, with characteristic elliptical case, has also been observed in considerable numbers in the same relation with pectinatus, the larva apparently feeding on the epiphytic algal growth. The larræ of both of these insects, after wintering on the algal-covered leaves, have emerged as adults in the spring. Other midges and caddis fies, flies (aquatic Diptera), moths (aquatic Lepidoptera), and beetles (Coleoptera) have been found in great numbers on the varions species of Potanogeton. The other smaller invertebrate animals most frequently seen on these plants are Crustacea, snails, and worms.

Another interesting relation existing between the Potamogetons and aquatic insect forms is seen in the striking resemblance between the cases of a caddis fly (Leptocericlæ) and the stipules of the leaf of P. amcricanus (fig. 75). The cases in which both larve and pupæ dwell are attached along the stems and leaves in so characteristic a manner as to become almost, if not quite, indistinguishable from the plant parts. 
Reighard (189.4) has expressed in a table "a part of the imperfectly known relationships existing between the various groups of plants and the invertebrate animals on the one hand and the fishes on the other." One of the great gaps in the clain of relations therein expressed is a lack of definite knowledge concerning the rôle of the higher plants.

Some definite research in this direction has been begun. Recent investigations on the food habits of aquatic insects have shown that the larger aquatic plants do serve as forage materials. According to Hart (1895), the larve of Nymphula sp. (Paraponyx), an aquatic lepidopterous insect, feed roraciously on Potamogcton natans. Needham (1907) mentions the presence of $N y$ mphe adren in the diet of Chironomus albistria, and Morgan (1912) found that the higher plant tissues formed an important part of the stomach content of Hay-fly larre. In riew of these investigations the leaves and other edible parts of Potamogeton were closely scrutinized for evidences of their use as food. In my own investigations the first indication that the living tissues of Potamogeton was being eaten was seen in the young growing tips of $P$. crispus, which had been transferred from a pond to an aquarinm in the laboratory. The leaves of several plants were mined by a small larval form which proved to be a chironomid (midge). The characteristic leaf nine is shown in figure 72 . Miss Tibury (1913), who was working in the Cornell laboratory on the feeding habits of the midge, taking advantage of this observation, reared her species, Chironomus caynge. Johannsen, mainly on $P$. crispus and entirely on Potamogeton.

On examining the leares of other Potanogetons it was found that practically all species were foraged upon to a greater or less extent. l,arral depredations were most common on $P$. Robbinsii. In this plant the aquatic lepidopterous larva Nymphula sp. (Parapon $\left.y^{\prime}\right)$ is the chief herbivore, and so voracious is its appetite that a large proportion of the growing tips are constantly being defoliated in the manner shown by figure 68 . Portions of the ieaf are cut ont also by the lara, applied together by means of silk, and used as a protective case or retreat during the larval and pupal stages. Nymphula sp). is by far the most conspicuous larva feeding upon $P$. Robbinsii, yet other important smaller forms are numerous. The limy incrustation that accumulates very freely on $P$. Robbinsii offers apparently especial inducements to certain case-making insects, as midges and caddis flies. Such larva are exceedingly numerous on this species of plant, and the limy incrustation is the clice material used in the construction of the cases.

A few of the chironomid larre that were common on $P$. Robbinsii collected at North Fairharen in October were segregated and fed exclusively on this Potamogeton. They' passed successfully through the pupal and adult stages and proved to be the midge, Chironomous aberrans. The larval and pupal stages have been hitherto unrecognized in the life history of this species. ${ }^{a}$

The leaves of $P$. amplifolizs were conspicuously mined by the dipterous larva If $y$ drellia sp. (Ephydridæ). The pupæ were collected on the leaves August 6 . Several flies and their parasites were reared from them, emergence occurring between August I 6 and 20. The larva makes a wide, irregular mine through the leaf, and in each case under observation pupates at the end of the mine toward the base of the leaf blade where the edges naturally roll together and form a protecting furrow (fig. 73). Nymphula sp. (Paraponyx) is also common on this Potamogeton and many of the young leaves are eaten by them. Oftentimes the larra cuts out a portion of the leaf for its case with the neat-

a Determinations of dipterous larve have been made by Prof. O. A. Johannsen; of caddis-fly larvx, by Mr. J. T. Lloyd. 
ness and precision of a leaf cutter bee (fig. 74), though usually there is less regularity of outline.

On the floating leaves of $P$. americanus colleeted early in Augnst were found eggs of Paraponyx and of chironomid. ${ }^{a}$ Those of Paraponyx covered broad areas of the under surfaces of the leaves and presented the appearance of mintte six-sided cells of honeycomb, yellowish in color. In a few days the larvæ hatched and began at once to feed and to cut portions from the leaves for larval cases. Fryer (1888), in connection with his studies on P. Auituns, mentions that the larve of Nymphula (IIydrocampa potamogata) entirely destroy the floating leaves of this species, and thus indirectly induce the development of fascicles of leares, structures which are analogous to the winter buds of $P$. obtusifolius. The eggs of the chironomid, which were found on the leaves of $P$. americanus, were inclosed in snall elongate cases blackish in color, suspended from the edges and from the underside of the leaf, and from the petiole. These eggs hatched within a few days, but their entire life history was not observed.

The leaves of $P$. obtusifolius harbor a large number of chirononids, and apparently offer a valuable supply of food to many of them. A few of the larræ were segregated in small dishes and supplied with fresh leaves of this Potamogeton. An undeseribed species of Chironomus was reared. Cricotopus trifasciatus and Tanypus fuzellus were the most abundant species on the leaves.

Other plant parts besides leaves were eaten. The tubers of $P$. pectinatus and the burs of P.crispuswere devoured by the larvæ of Paraponyx and by the larvæ of the Chironomidx.

The underground stems of $P$. pectinatus ${ }^{b}$ are provided with large and numerous air spaces (fig. 66), and these were found to be an important air-supplying source for the Donacia larvx. The larvæ attached to the subterranean stems of this Potamogeton were collected from the muddy substratum at North Fairhaven August if, 1913. Stems on which the larvæ were not attached showed, quite generally, the characteristic punctures, or double sears, made by the eaudal spines in tapping the air supply.

Jepson (1905) ealled attention to the value of the tubers of $P$. pectinatus in the diet of our wild game birds. He says, "The diving ducks, such as the canvasback and broadbill, eagerly seek these tubers, devoting most of their time to this pursuit until the Guck-shooting season opens." NeAtee (1911) and Thompson (1913) in their researehes on the diet of wild game birds have shown that a large percentage of the food taken is Potamogeton.

The stomach content of 5 canvasbacks has come under my observation recently. One duck shot in October had been feeding in rich aquatic meadows where Potamogetons flourished with Myriophyllum, Elodea, ete. Its stomach was filled exelusively with tubers of $P$. pectinatus. Four ducks shot at the close of the season in January had apparently exercised a choice in the matter of food. Feeding in an abundant mixed vegetalion, they had selected only Potamogeton-P. Fresii and P. pusillus. The parts of the plants available were the winter buds which at this season have settled in the mud at the bottom along with the hibernacula of Myriophyllum, Elodea, and other aquatic plants.

a During subsequent observacions in June. igr. masses of eggs almost infinite in variety and number have been found attached to the stems aud leaves of the various Potamogetous. It would seem that these plants, diverse as they are in babit and form, offer especially suitable conditions for the attachment of the eggs of aquatic animals. The eggs of the water mite (Hydracarina) are exceedingly abundant. The eggs of insects that have been recognized are as follows: Stratiomyidx, Coriscid $x$, Gyrinidæ, Donaciinæ, Hydrophylidæ, Pyralidx, Cordulinx (Tetragoneuria), Hydrobatid:e and Tricoptera.

o since this observation was recorded Douacia larve have been found ou the underground stems of $P$. americanus. 


\section{SPECIES OF POTAMOGETON AND THE ANIMALS FORAGING UPON THEM.}

To facilitate reference, a list is given of the species of Potamogeton, together with the smaller animals which have appeared to be intimately associated with them. Other forms of animal life were often found upon these plants, but none seemed to be so characteristically on their own ground, so to speak, as the forms listed below. Those animals are starred (*) which have been observed feeding on the living plant tissue.

List of Potamogetons and Smal. Aximal forms Associated Miti Tiem, $a$

\begin{tabular}{|c|c|c|}
\hline & Plant. & Animal \\
\hline P. amcricanus.... & $\begin{array}{l}\text { Mollusecta } \\
\text { Monca }\end{array}$ & 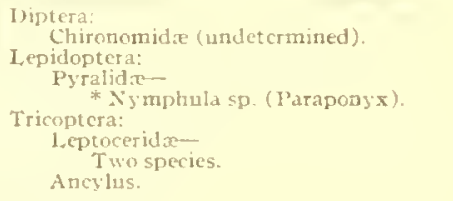 \\
\hline P. amplifolius....... & $\ldots \ldots \ldots \ldots \ldots \ldots$ Insecta & $\begin{array}{l}\text { Diptera. } \\
\text { Ephydrida- } \\
* \text { Hydrellia sp. } \\
\text { Chiromornida- } \\
* \text { Chimnomus sp. } \\
* \text { Tanytarsus sp. } \\
\text { Trimptera: } \\
\text { Cndetrmincd. } \\
\text { L.epiloptera } \\
\text { Pyralida- } \\
* \text { Nymphula sp. (Paraponyx). } \\
\text { Ancylus. }\end{array}$ \\
\hline P. perloliatus..... & $\ldots$... Insecta & $\begin{array}{l}\text { Diptera. } \\
\text { Chronomida- } \\
* \text { Tanytarsus sp. }\end{array}$ \\
\hline P. crispus . & Insecta & $\begin{array}{l}\text { Diptera } \\
\text { *Chironornidxe (undetermined). } \\
\text { Lepidoptera: } \\
\text { Pyralida- } \\
* \text { Nymphula sp. (Hydrocampd). }\end{array}$ \\
\hline P. zosterifolius..... & $\ldots \ldots \ldots \ldots \ldots \ldots \ldots$ Insecta & $\begin{array}{l}\text { Diptera: } \\
\text { Chironomidam } \\
\text { * Tanytarsus sp. } \\
\text { Lepidoptera. } \\
\text { Pytalida- } \\
\text { * Nymphula sp. (Pasaponyx). } \\
\text { Tricoptera: } \\
\text { Lndetermined. }\end{array}$ \\
\hline P. obtusifolius ..... & Insecta. & $\begin{array}{l}\text { Diptera: } \\
\text { Chironomide- } \\
\text { * Chirononous sp. } \\
\text { Cricotopus trifasciatus. } \\
\text { Tanytarsus flavellus. }\end{array}$ \\
\hline P. pectinatus ... & .. Insecta.. & $\begin{array}{l}\text { Diptera: } \\
\text { Churonomida- } \\
\text { Tanytarsus flavellus } \\
\text { Cricopteris sp. } \\
\text { Trimptera: } \\
\text { Hydroptilide (in autumn). } \\
\text { Colemptera } \\
\text { Donacine- } \\
\text { Dutlacia sp. }\end{array}$ \\
\hline $\begin{array}{l}\text { P. pectinatus } \\
\text { (Gigantic form) }\end{array}$ & Crustacea. & $\begin{array}{l}\text { Diptera: } \\
\text { Chironoraid:- } \\
\text { Chirumenous sp. } \\
\text { Tanytursus sp. } \\
\text { Amphipoda (very abundant). } \\
\text { Gammarus. } \\
\text { Hyallela. } \\
\text { Eucrangony } x\end{array}$ \\
\hline P. Robbinsii & Insecta. & $\begin{array}{l}\text { Diptera: } \\
\text { Chironomida- } \\
\text { * Chronomus aberrans. } \\
\text { Tanytarsus sp. } \\
\text { Tricoptera- } \\
\text { Undetermined. } \\
\text { Lepidoptera: } \\
\text { Nymphula sp. (Paraponjx). }\end{array}$ \\
\hline
\end{tabular}

a A Potamogeton which came under casual observation only. $P$. Epihydrus, may he mentioncd as an important addition to the plants actually foraged upon hy insect Larve. Several specimens of this species of Potamogeton, crollected at Spencer Lake in August. were quite thickly dotted with caddis-fly larva (Leptoceridx), which werc leeding upun the fresh green leaves. 
The Mollusca-Planotbis, Limnea, and Physa-were common on all of the Potamogetons.

These observations on the animal life associated with the Potamogetons afford an additional contribution to the biological relations of the Chironomidæ, Pyralidie, Leptoceridæ, Hydroptilidæ, and Ephydridæ, groups in which one or nore members have been observed in their feeding operations. Of these animals it has already been recorded by Reighard (1894) that the Chironomidx are an important fish food. Scattered reference is made by others of the value of aquatic insect larvæ in the diet of fish. The fact that these insects eat the living plant tissue of the Potamogetons adds greatly to the importance of these plants from an economic standpoint.

\section{CONCLUSION.}

In all contributions bearing on the life conditions of the Potamogetons, the prominence of these plants in the shoal waters has been recognized, and where special effort has been directed toward the study of their life relations, an economic value has been ascribed to them. The present investigation affords further evidence of the economic value of these plants, and contributes the results of observation and experiment on the cultivation of sereral species. These results warrant the expenditure of additional thought and effort on what purports to be one of the most important resources of our lakes, ponds, and streams. 
AgARDh, J. G

\section{BIBLIOGRAPHY}

1852. (Some observations on Potamogeton pectinatus.) Botanische Verhandlungen der $\mathrm{K}$. Ascherson, P and Grati p. 755-75

1907. Potanogetonacex, Das Pflanzenreicli, +, II, p. I84, text fig. 22I. Leipzig.

BADE, E

rgog. Das Süswasser-Aquarium, p. Sg6. Berlin.

BAUMANN, E.

IgIr. Die Flora des Untersees. Stuttgart.

BENNETT, ARTHIR.

I880. Notes on pondweeds. Joumal of Botany, P. 380.

BritTon, N. L., and Brown, A.

I9I3. Illustrated flora of the northern Inited States, Canada, and the I3ritish possessions. 3 vols.

CITAMISSO and SCHLECHTEND.

Clos, D.

I827. Linnea, vol. 2, p. I57-233 1856. Hode de propagation particulier au Potamogeton erispus L. Bulletin de la société Bo-
tanique de France, t. 3, p. 350-352. Constantin, J 1884. Recherche sur la structure de la tige des plantes aquatiques. Annales des Sciences Natu-
relles, o sér., p. $287-331$, pl. I. $8^{-17}$. 1835. Observations critiques

la Société Botanique de Francerte des feuilles des végéteaux aquatiques. Bulletin de 1886. Etudes sur les feuilles des plantes 32,1$) \delta_{3-92}$

DAvis, Chiss. A t. $3, \mathrm{p} .94-102, \mathrm{pl}, 2-6$

Ig07. The flora of Walnut Lake. In: Report of Biological Survey of Michigan. Published by DUDLEY, WILLIAM R.

Dyсnе, L. L.

1910. Ponds, pond fish, and pond fish culture. Part I, Bulletin no. \&, State Department Fish ESENBECK, ERNST.

Fischier, G.

1914. Beiträge zur Biologie der Gattungen I'otamogeton und Scirpus. Flora, bd. 7, p. I5I-2I2

Ip07. Die

FORBES, S. A

Gesellschaft, bd. Ir, p. 20-162

I8so. The foud of fishes. I $S=-9$.

I888. Studies of the food of fresh-water fishes. Ibid., vol. 2, 1). 433-474.

FRlER, ALFRED

I888. Notes on pundwecds. Juurnal of Botany, wol. 26, p. 273-2-8.
I900. The Potamogetons of the British Isles. Purts 
Glück, Hugo.

1905-6. Biologische und Morphologische Untersuchungen ïber Wasser und Sumpfgewäclise. 2 vols. Jent.

Hankinson, Thos. L.

1907. A biological survey of Walnut Lake, Michigan. Report of Biological Survey of State of Michigan. p. 288, pl. 60,2 maps.

$\mathrm{H}_{\mathrm{ART}}, \mathrm{C} . \mathrm{A}$.

I895. Entomology of the Illinois River and adjacent waters. (In his: Lepidoptera, p. I6.4-I $8_{3}$.)

HiLl, E. J.

Art. 6, Bulletin Illinois State Laboratory Natural History, vol. 4, p. 1.48-28.4, nl. I5.

I898. Eleocharis melanocarpa, a proliferous plant. Bulletin of the Torrey Botanical Club, vol. 25, no. 7, P. 392-394, pl. I.

1898. Potamogeton Robbinsii. Botanical Gazette, vol. 25, p. I95-196, pl. I5.

HOLFERTI, G. M.

Igor. Ovule and embryo of Potamogeton natans. Botanical Gazette, vol. 31, p. 239-346, pl.

HUL, E. D.

Igr 3. The advance of Potamogeton crispus. Rhodora, vol. I5, no. 177, p. I71-172.

IRMISCH, THILO.

I851. Über die Inflorescenzen der deutschen Potameen. Flora, no. 6, p. 81-93, pl. I.

1858. Ủber einige Arten aus der Naturlichen Pflanzenfamilie der Potameen, p. 56, pl. 3. Berlin.

JEPSON, W. L.

I905. Where ducks dine. Sunset Nagazine, February.

KERNER, A., and OLIVER, F. W.

I895. The natural history of plants, their forms, growth, reproduction, and distribution. 2 vol. New York.

Macgillivray, Alexx. D.

1903. Donaciine. (In his: Aquatic Chrysomelida, a footnote, p. 325.) Bulletin New Iork

MCATEE, W. L. State Nusenm, no. 68, p. 288-327, pl. 2I-3I.

rgí. Thrce important wild-duck foods. Circular no. 8I, Bureau Biological Survey, United States

MICKLE, G. R. Department of Agriculture, p. I-Ig, fig. Ig.

IgI2. Possibilities of northern Ontario as a breeding ground for ducks (published by L. K. Cameron), p. $3-8$, text fig. 2. Toronto.

I913. The increase of the food supply for ducks in northern Ontario. Ibid., p. I7, text fig. 3, - figs. I-5 $\mathrm{b}$

Morgan, Anna Haven.

I9I3. A contribution to the biology of May flies. Amnals of the Entomological Socicty of America, vol. 6, no. 3, p. 37 I-4I 3 , text fig. 3, pl. $42-54$.

Morong, Thos.

1893. The Naiadacee of North America. Memoirs of the Torrey Botanical Club, vol. 3, no. 2, $1892-93, \mathrm{p} .65, \mathrm{pl} .55$.

NEEDHAM, J. G.

1907. Notes on the aquatic insects of Walnut Lake. In: A biological survey of WaInut Lake. Michigan. Report of Biological Survey of State of Micligan, p. 252-271, fig. r9-21, pl. r, I map.

PIETERS, A. J.

1894. The plants of Lake St. Clair. Bulletin of the Michigan Fish Commission, p. 10, I map. Lansing.

IgoI. The plants of western Lake Erie with observations on their distribution. Bulletin United

POND, R. H. States Fish Commission, vol. 21, p. 57-79, text fig. 9, p1. 8. Washington.

I903. The biological relations of aquatic plants to the substratum. Report of United States Commission of Fis'n and Fisheries, p. $48,3-526$, fig. 6 . Washington.

(In press). The larger aquatic vegetation. American Fresl Water Biology, 1) 32, fig. 20. 
RATNKIAER, C.

1903. Anatomical Potamogeton studies and Potamogeton fluitans. Botanisk Tiddskrift, vol. 25, no. 3, p. $253^{-2 S o}$, text fig. 9 .

REICHENBACH, L, L゙DOVICT'S.

IS45. Icones Florx Germanica et Helvetica, vol. ;, p. 40, pl. 7 i.

REIGHARD, J. E.

I894. A biological examination of Iake St. Clair. Bulletin Michigan Fish Commission, no. 4, p. 6o, text fig. I, pl. z, I map. I ansing.

SAT'VAGEAU, M. C.

I889. Contribution a l'étude du systène mécanique dans la racine des plantes aquatiques les Potamogeton. Journal de Botanique, $3^{e}$ année, no. 4. p. 6I-S2, fig. 9.

1800. Observations sur la structure des feuilles des plantes aquatiques. Ibid., $4^{\circ}$ année, p. $4 \mathrm{r}, 68$, II $7,129,173,181,221,237$.

ISqr. Sur les fenilles de quelques Monocotyledones aquatiques. Annales des Seiences Naturelles Botanique, $7^{p}$ sér., P. I03-290.

IS94. Notes Riologiques sur les Potanogeton. Jonmal de Botanique, ge année, 1). I, 21, 45, 98, II $2,140,166$, fig. 3 I

SHELFORD, Victor F:

1913. Conditions of existence of aquatic animals, $1,5^{8-72}$. In l1is: Animal communities in temperate Atnerica. Clicago, University of Chicago press, 1913.

SHERFF, E,ARL, E.

IQI3. Vegetation of Skokic Marslx. Bulletin of the Illinois State Laboratory, vol. 9, art. I I, p.

SCHEXCK, H. $575-614,11.86-97$

1S36. Die Biologie der Wassergewächse, pl. 2. Bonn. Entry taken from a review in Botanisehes Centralblatt, no. 24. 1.355.

Timoneson, H. D.

I807. Repurt on Plants. In: The biological examination of Lake Michigan. Aplendix I, Bulletin Michigan Fish Commission, no. 6, p. 72-75.

Thonpson, R. B.

1913. Wescription of edible plants. In: The increase of the food supply for ducks in northern Ontario. Toronto, p. $8-1 \%$, text fig. 2 , fig. $1-5 b$.

TILBCRY, MLARY RETII

I913. Notes on the feeding aud rearing of the midge, Chironomus cayvgre jolıansen. Journal New York Entomological Suciety, vol. 21, p. 305-308.

TITCOMB, JOHN W.

rgoo. Aquatic plants in pond culture. Bureau of Fisheries, doc. no. 643, 3 I p., 32 text fig., 2 pl. [SPENSKIJ, E. E.

I9I3. Zur Plyylogenie und Ökologie der Gattung Potamogeton. Moscon. Entry taken from a note in Flora, bd. 7. P. IS-

IV.ARMING, ETEGENE.

1909. Oecology of plants. An introduction to the study of plant communities, p. 422. Oxford.

IVIEG.AND, K. II.

159s. Embryology of Potamogeton. Botanical Gazette, vol, 25, p. I I6-I I 7 .

1899. Development of microsporangium and microspores in Fotamogeton. Ibid., vol. $28, \mathrm{p}$. $328-359, p^{l} \cdot 24^{-25}$

IORE, H.ARLAN.

Igo5. The hibernacula of Ohio water plants. Ohio Naturalist, vol. 5. no. 4, p. 3. fig. 3. Columbus. 


\section{EXPLANATION OF PLATES.}

All of ligures on Plates XIXIV-XXXIX, with the exception of the photo-micrographs, are plotographs of plants lloating in water, in aquaria, or in specinten jars.

\section{PL.ATE XXil}

Fic. I. Polamogeton américanus, seed, $\mathrm{I}_{2}$ t times natural size.

FIG. 2. Polurrogiton ameticanus, scedling 5 days old, I' 2 times natural size.

Fìc. 3. Polamogeton americanus, seedling 14 daysold, I ${ }^{\mathrm{T}}$ times natural size.

FIG. 4. Potamogeton americanu, seedling of four months, I: natural size; A, winter buds.

Fitg. 5. Pofumogeton americanus, gerninating winter bud, natural size; the last two winter buds belated in development. Aquarium specimen, Jannary 24,1914 .

Fíg. 6. Potumogeton amcritumu, rootstoek with winter bud A, natural size. September.

\section{Plate XXIII.}

Fig. 7. Polamogeton amplifolius, rontstock, I's natural size; A, A, A, young shoots which continue to grow slowly througl winter. November.

Fíg. 8. Potanogcton heicrophyllus, submerged plant, natural size; A, tuberous rootstock; B, B, submerged shoots; $a, b$, and $c$, details of leaves. May 4 .

Fig. 9. Potamogeton hetcrophyllus, rootstock not tuberous, natural size. July 7 .

Fig. Io. Potanoycton heterophyllus, tuberous rootstock, natural size. July 7 .

Fig. It. Potumogiton heterophyllus, tuberous rootstock, natural size; A, A, incipient shoots November $i_{7}$.

\section{PLATE XXIV.}

Fig. 12. Potumogcton heterofhyllus, typieal habit of land form, 1..2 times natural size. Terminal portion of rootstock tuberous. July 7 .

Fig. I3. Potamogeton heterophyllus, terminal portion of rootstock showing tendency to become tuberous, I, a times natural size. July 7 .

Fic. If. Same, more advanced stage, I z times natural size. July :-

Fig. I5. Potomogetun hetcrophyllus, aquarium specimen, natural size; A, tuberous internode placed in aquarium in November; 13, B, new shoots and rootstock. January 26.

\section{PLATE XIT.}

F1G. I6. Polamogeton hterophyllus, aquarium specimen, natural size; A, B, C, D, new shoot and tuberuus rootstocks in various stages of growth. March I4.

Fıg. I- Potomogeton heterophillus, aquarium specimen, natural size.

FIG. IS. Potumoqeton perfoliatus, winter shost showing elongation of internodes, natural size; $A$, leathery scale: $a$. detail of scalk. June.

Fig. 19. Growing tips of same.

\section{PLATE XXVI.}

Fig. 20. Polamogeton crispus, recumbent branch, slowing development oi sew shoots on old stem, I; natural size. Warch.

FIG. 2 I. Putamogeton crispus, spicular bur, Iz times natural size. Aquarium. July.

Fig. 22. Potamoyeton crispus, denticulate bur, 3,4 natural size; a, detail of leaf with denticulate base, 2 times natural size; $I$, line delimiting starch storage.

Fig. 23. Potamogeton crispus, spronting bur, I I times natural size. Narch.

Iirg. 24. Potamogeton crispus, denticulate bur with sprout, nitural size. Aquarium. July.

FIG. 25. Potamoycton crispus, spicular bur with sprout, z natural size. Aquarium. July. 


\section{PLATE XXVIH.}

Fig. 26. Potomoacton crispus, cutting showing bur development, i natural size; A, immature burs. Aquarium. March 22-April 7 .

Fig. 27. Polamogeton crispus, sprouting bur, showing development of rootstock and erect shoots, natural size.

Fig. 28. Polamogelon crispus, shoot with spieular bur at base, natural size.

Fig. 20. Potamogeton crispus, similar strueture rooting above tip of bur, natural size.

FIG. 30. Potamogeton crispus, bur formation at tip of branch, I+ times natural size. Aquarium,

\section{PIATE XXVIII}

Fig. 31. Polomogeton crispus, subteranean stem, slowing hur in axil of scale, natural size. June.

Fì. 32. Potomogelon crispus, sprouting bur, 3i niltural size. Miarch,

Fíg. 33. Potamogctur zosterifolius, winter lud, $3_{4}$ natural size. Oetoher.

FIG. 34. Potomonton zosterifolius, long section of winter bud, $\mathrm{I}^{1}=$ times natural size.

Fig. 35. Potomogeton zosterifolius, winter bud sprouting. 'r's natural size. April.

\section{PLATE XXIS.}

Fig. 36. Potamoqeton fliformis, habit sketch. ${ }_{2}^{2}$ natural size. July".

Fig. 37. Potamogiton filiformis, detail of tuberous rootstock, ${ }^{1}{ }_{4}$ times natural size.

Firg. 38. Polamogiton pectinulus, young plint developing from tuber $A,{ }^{2}$, natural size. May.

Fig. 30. Lotamogiton pectinatus, series of tubers, slender form of Dutley, 3 ; natural size.

Fig. 4o. Polamoueton patinatus, tubers, showing details of early growth, 1 ' 2 times natural size.

\section{PLATE: TXX.}

FiG. 41. Polomogelon pectinatus, tubers of two suceessive seasons; A, old; 13, Joung; C. crect stem; D, subterranean stem; $I^{\mathbf{t}}{ }_{2}$ times natural size.

Fig. 42. Potumoaton pectinotus, terminal portion of subterratiein stcm, I $\mathrm{I}_{2}$ times natural size, A condition which may be present from June to Oetober.

Fig. 43 . Potomogeton pectinatus, mature portion of reotstock bearing tubcrous runners; A, tuberbearing runner; natural size. September.

Fig. 4t. Potamogeton pectinatus, spray showing fruiting spike and tuberous runners, A, B, C, 23 natural size; $a$, detail of runner: A. A, young green sliwets.

\section{PLATE SXXI.}

FIG. 45. Potamogeton pectinalus, plant developed in aquarium, suspended in water, I, natural size; A, old tuber which produced plant; B, young tuber.

FIG. 46. Potamogeton pecinatus, sprouting seed, 3 times natural size.

FIG. 47. Same, later stage, 3 times natural size.

Fig. f5. Potamoquton pectinatus, seedling about 10 days old, outer testa of seed removed, I + times natural size; $a$, inner hard testa, showing characteristic lid-like portion thrust open, I's times natural size; $b$, seedling with hiud testa of sced removed showing foot-like expansion.

Fig. 49. Polomogiton pectinafus, scedling thrce weeks old, natural size.

\section{PLATE XXYII}

Fi1G. 50. Potomogcton pectinatus, gigantic form of Duclley, runner B, from base of ereet sloot $A$, Iz natural size; C, tuber; D, D, D, young green shoots; 1,2 , secondary runnors. November.

Fig. 51. Potomogeton pectinatus, gigantic form of Dudley, tuber devoid of seales, I ${ }_{2}$ times natural size.

FIG. 52. Polamogiton pectinaius, gigantic form of Dudley, portion of a tuberous runner, natural size.

FIG. 53. Potomogeton pectinalus, gigantic form of Dudley, growing tip of secondary runner, natural size. 


\section{Plate XXTIII.}

Fig. 54. Potamogeton pectinatus, gigantic form of Dudley, sprouting tuber, I'ś times natural size. Aquarium, February.

Fig. 55. Potamogeton pectinatus, gigantic form of Dudley, tuberous runner, natural size.

Fig. 56. Pofamogeton pectinatus, spray, showing cases of chironomids, natural size. SeptemberNorember.

Fig. 5i. Pofamogeton Robbinsii, characteristic regetative structure, rooting at nodes, I $1 / 2$ times natural size. May.

\section{P1.ATE TXXIT.}

FIG. 5S. Potamogeton amplifolius, rooted tip of branch, a propagative structure. April.

Fro. 59. Potamogeton crispus, germinating burs. October.

FIG. 6o. Potamogeton coispus, burs in various stages of development. June.

\section{PIATE TETS.}

Frg. 6r. Potamogeton pectinalus, gigantic form of Dudley, erect axis of plant, 5 feet 2 inches tall, bearing rmner at base of stem. November.

FIG. 62. Potamogeton pectinatus, gigantic form of Dudley, portiun of leafy spray showing tubers. November.

\section{Pi,ate XXxvi.}

Fig. 63. Potamogeton obtutsifolius, winter buds. October.

Fig. 64. Potamogeton obfusifolius, erect axes bearing winter buds. October.

Fig. 65. Potamogeton zostorfolius, sprouting winter bud. Aquarium specimen. February.

$$
\text { ILATE XXYTIL. }
$$

FIG. 66. Potamogeton pectinatus, cross section through stem, showing numerous air spaces.

FIG. 0\%. Potamogeton Robbinsi, branch, showing points where dismemberment occurs, I, 2, 3.

FIG. 68. Potomogeton Robbinsii, branch defoliated by larx of Nymphula sp. (Paraponyx). Larval cases, $1,2,3$.

\section{PLATE XXXIIII.}

Fig. 69. Potomogeton Robbinsib, photo-micrograph of section through old stem, showing arrangement of mechanical tissue.

Fig. 70. Detail of fig. 60

FIG. 7I. Potamogeton crispus, photo-nicrograph of section througl stem of starch-filled vegetative structure; $a$, cell with starch grains. November.

\section{PLATE XXXIX.}

Frg. 72. Potamogeton crispus, leaves, showing characteristic leaf mining of chironomids.

Fig. 73. Potamogeton amplifolius, leaves, showing characteristic mines of II drellia sp.; $a, b, p u p a$ cases at end of mines. August.

FIG. 74. Potamogeton amplifolius; $a, b$, leaves, showing circular pieces cut away by larva of $\Lambda^{*} y-$ phula sp. (Parapon)'x); r, larva in case; c, dead leaf, showing cases of Chironomus sp.

FIG. 75. Potamogeton americanus, spray showing attachment of cases of caddis fly (fam. Leptoceridæ); $a$, case of caddis $\mathrm{fly} ; b$, stipule of leaf. June 3 I, IgI. 

HUIL. I. S. HS. Ii., IU13.

IITI XXII.

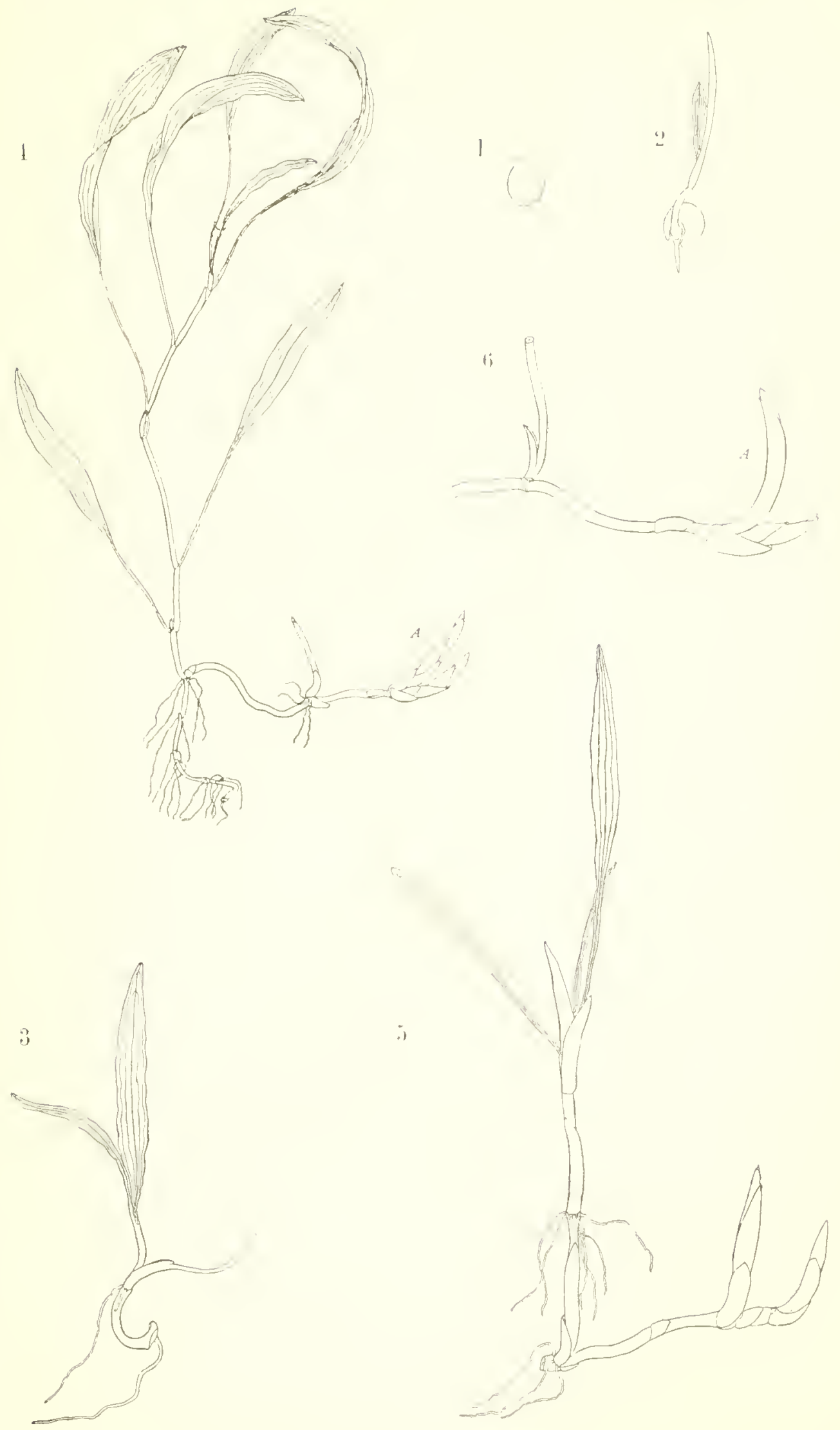



BCI.I. IT. S. IS. F., IUI,

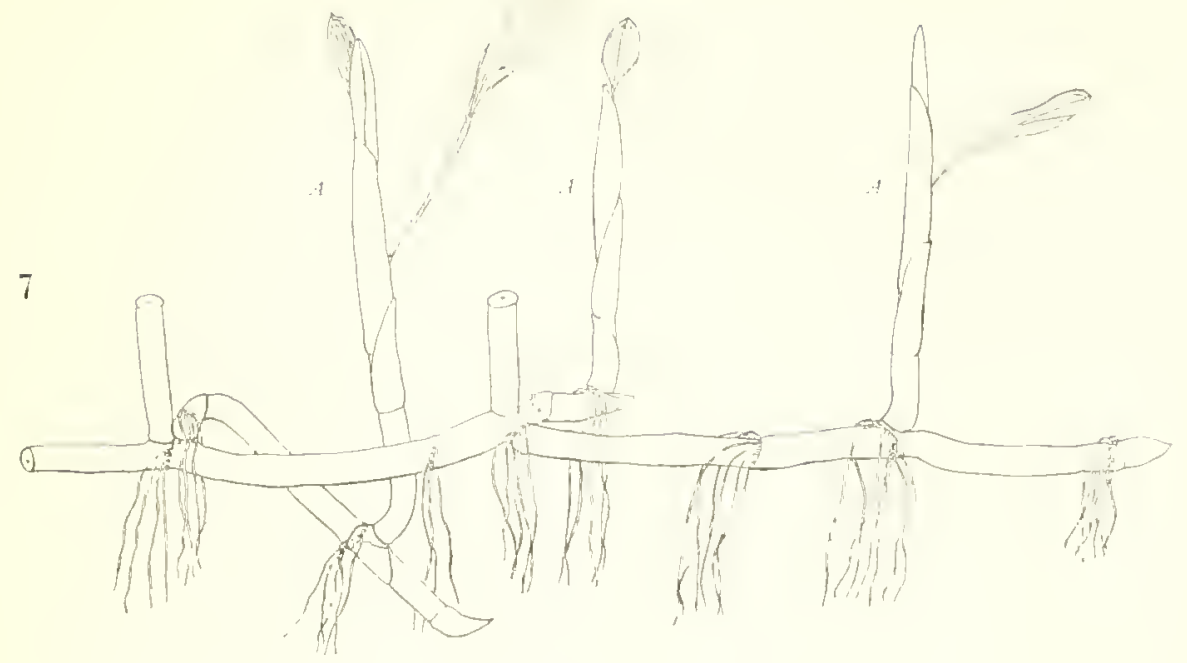

10
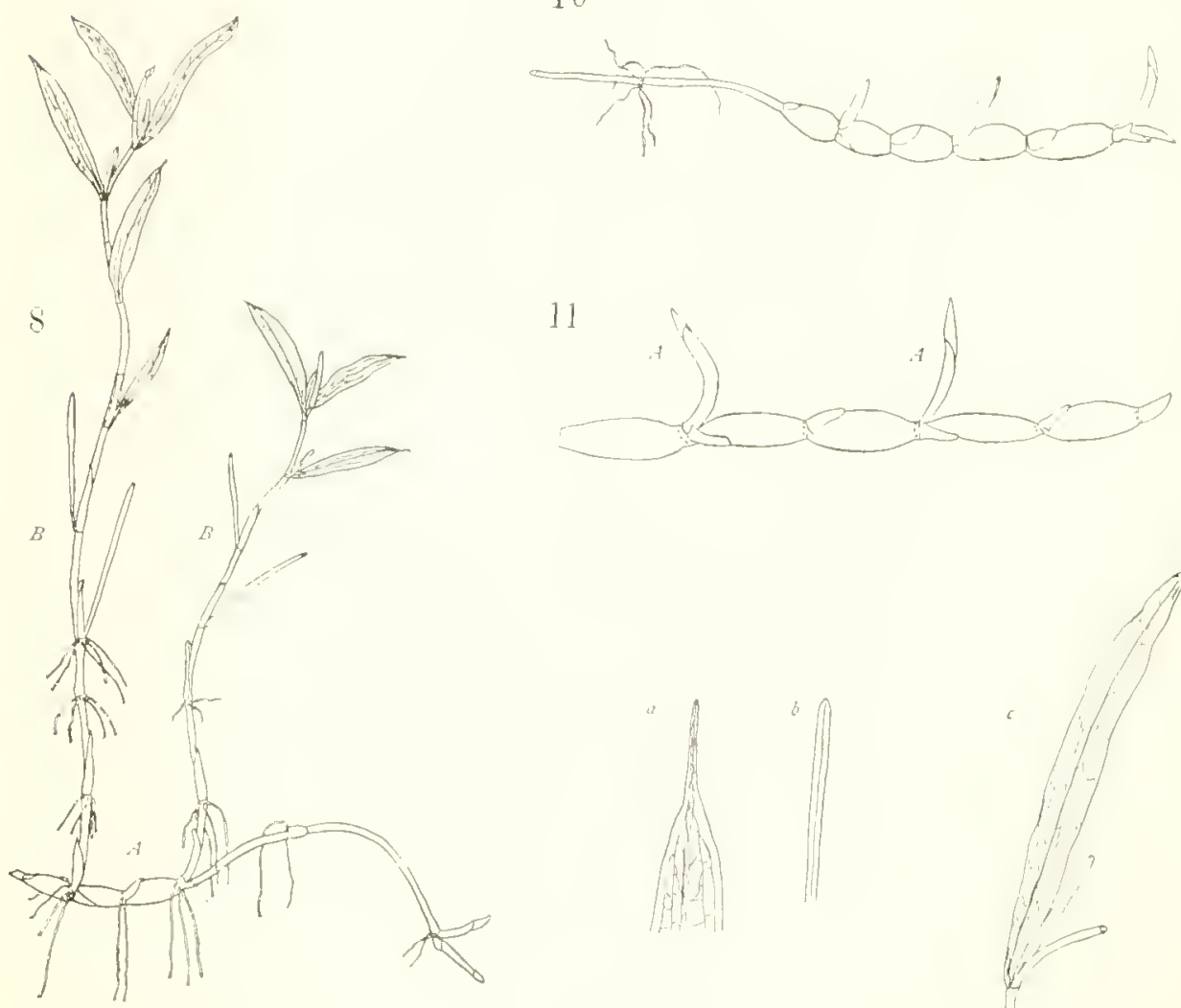

11
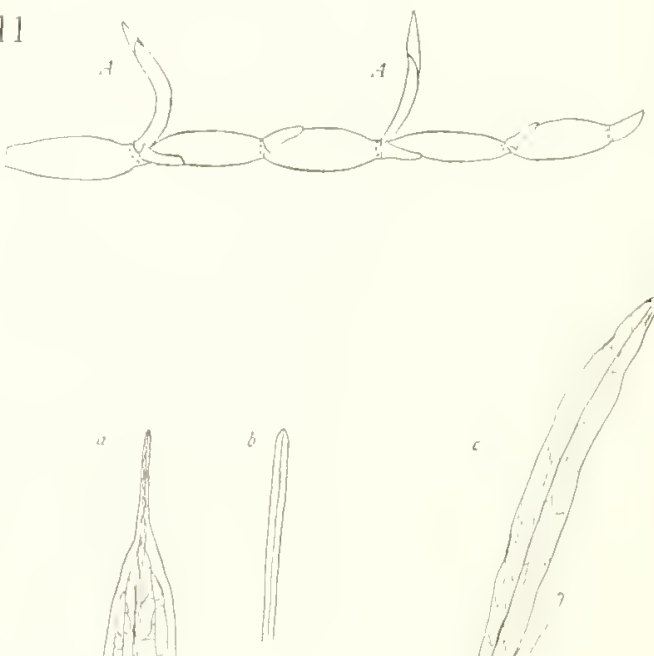

Pi.ATli RXII.

7

Pl.st 

IBTI. T. S. IS, F., IOIS.

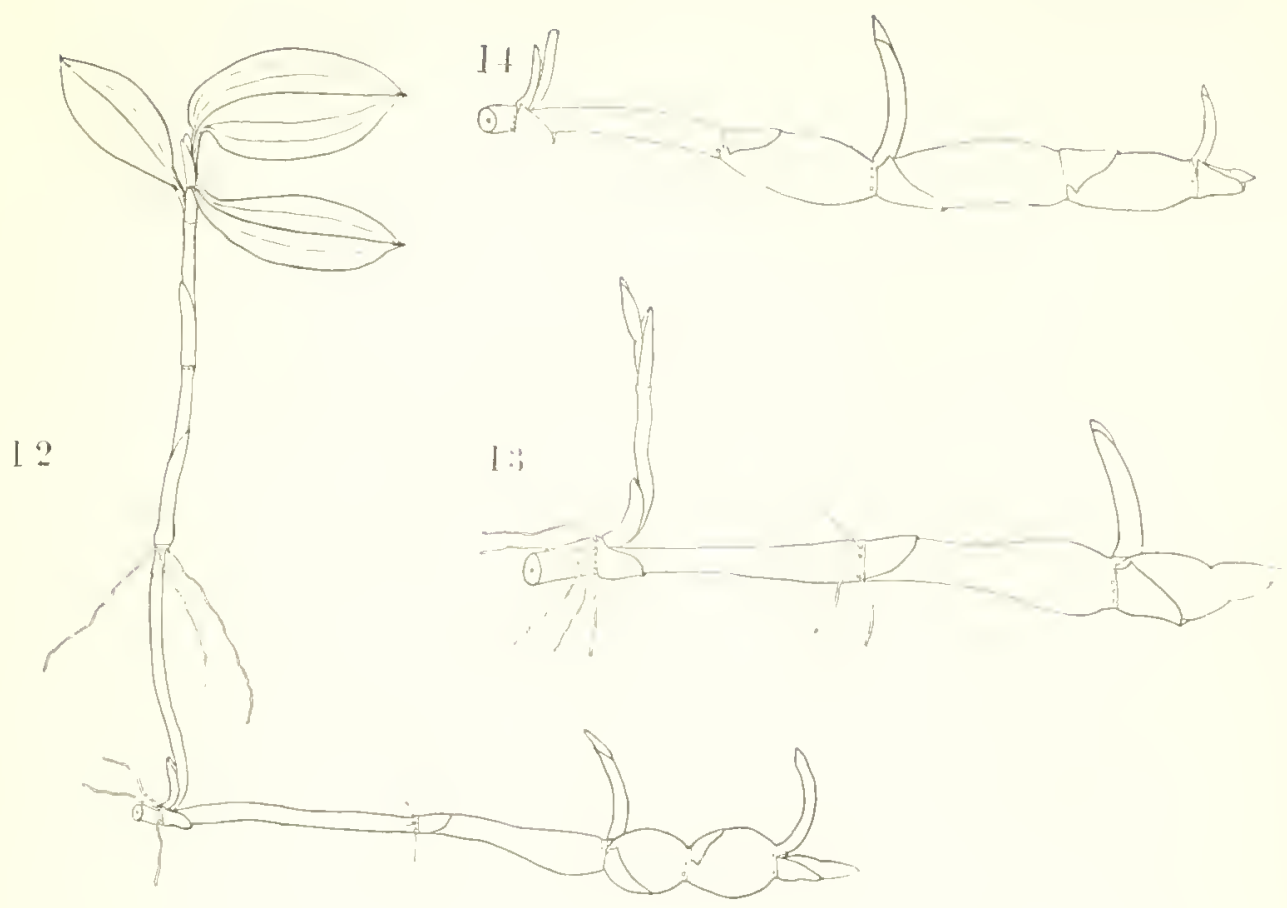

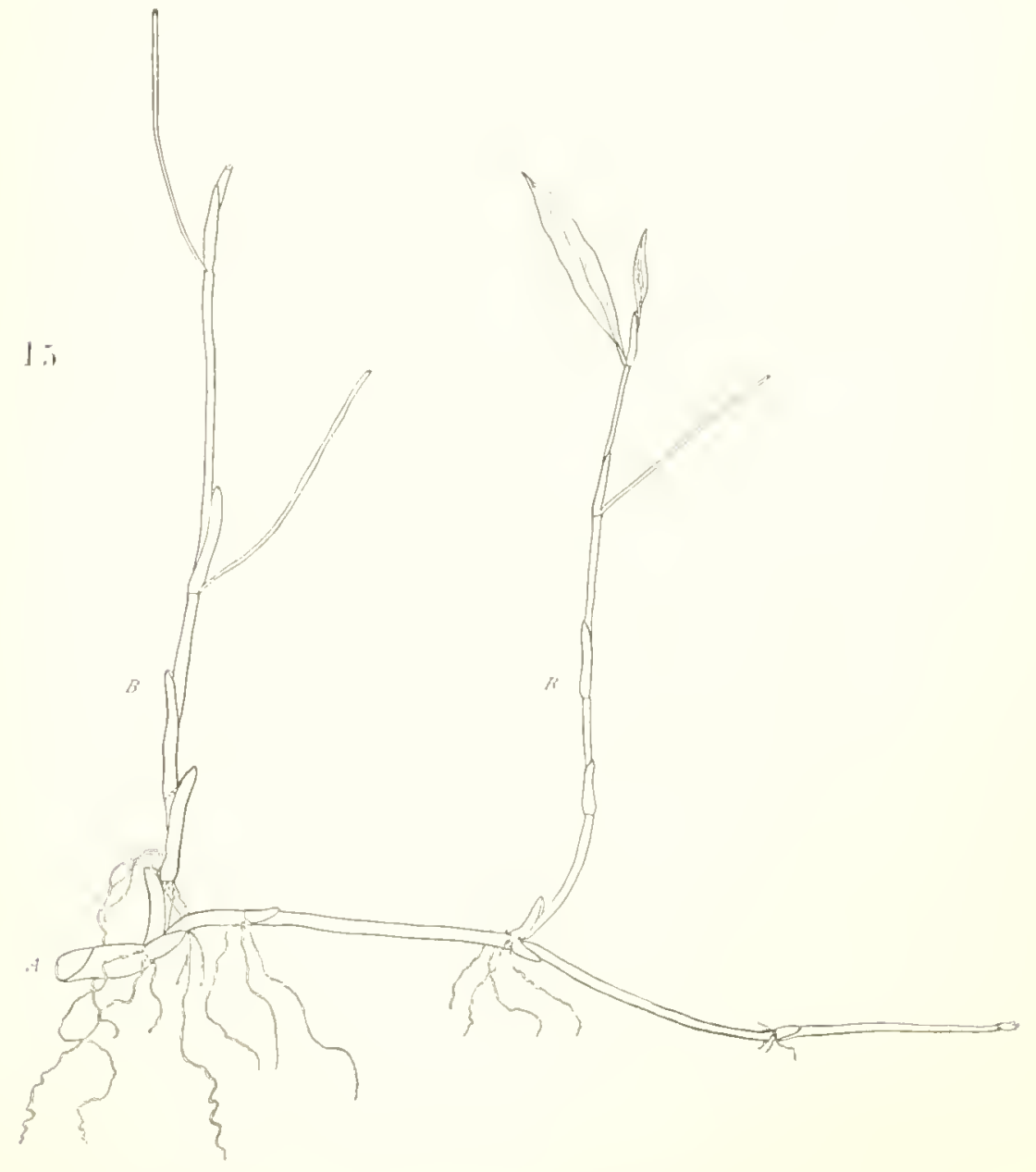





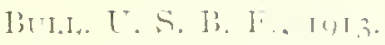

T'INT: NAT'.
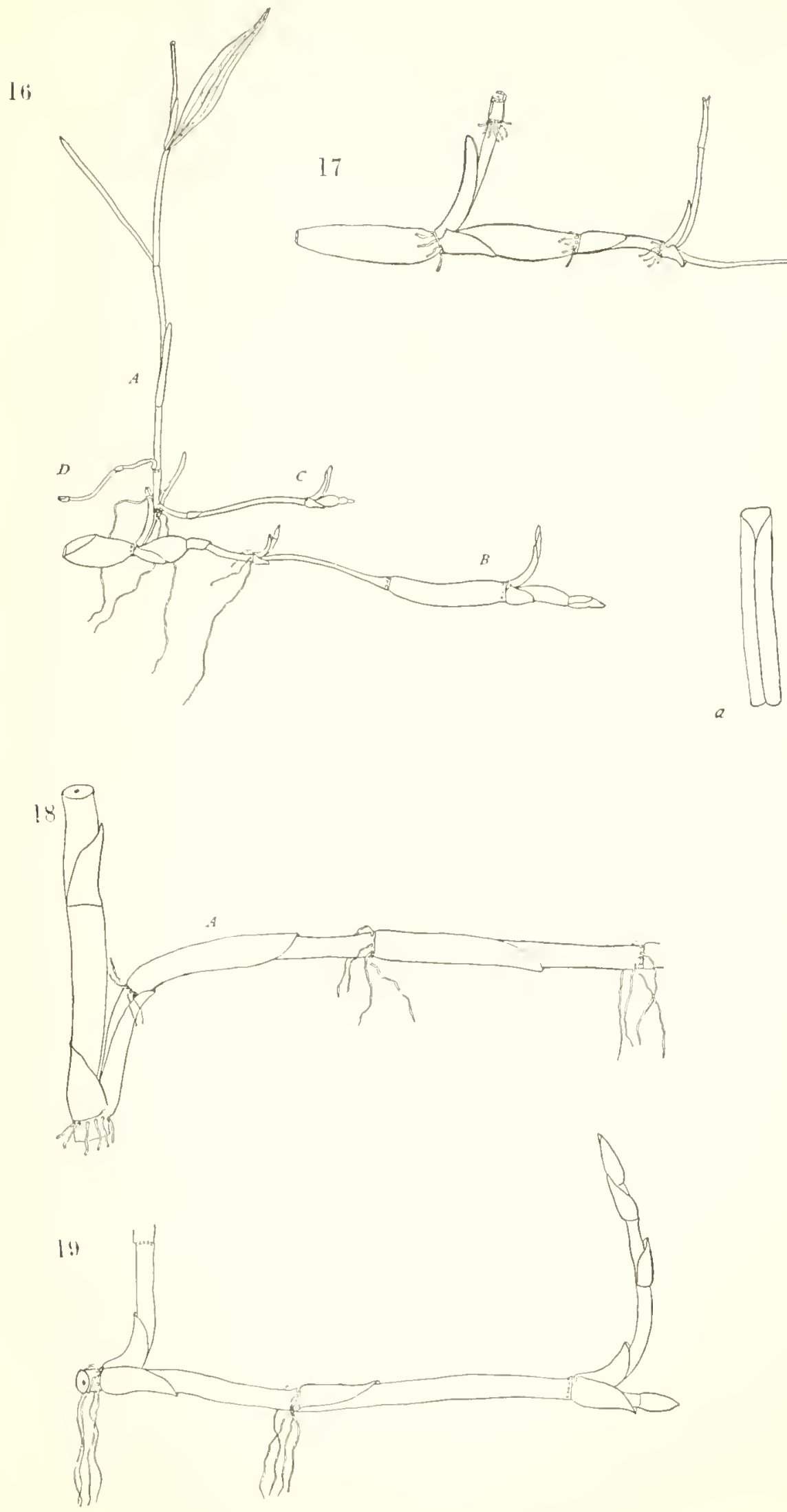



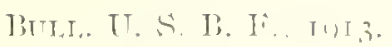

I'ITI XXYI

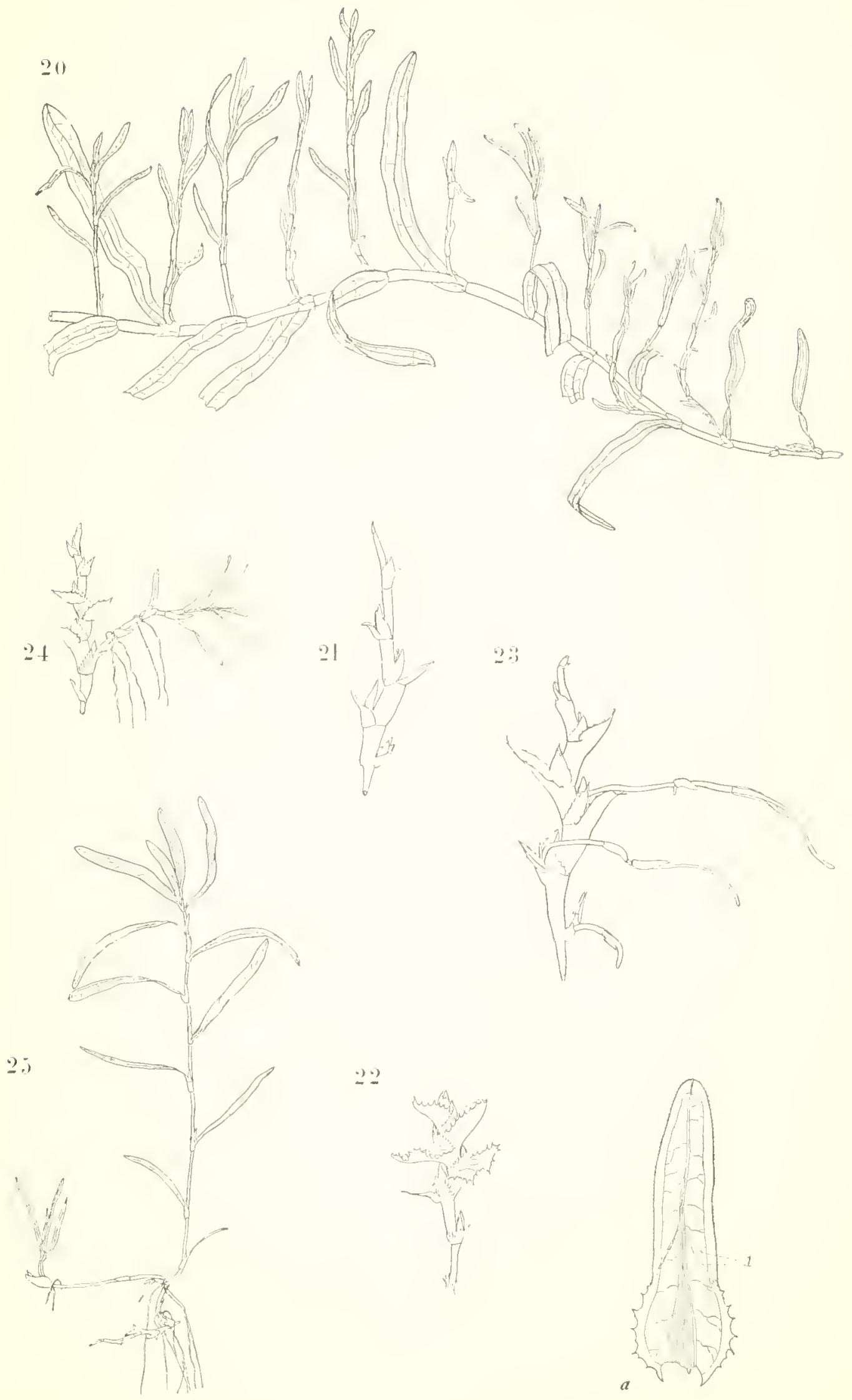





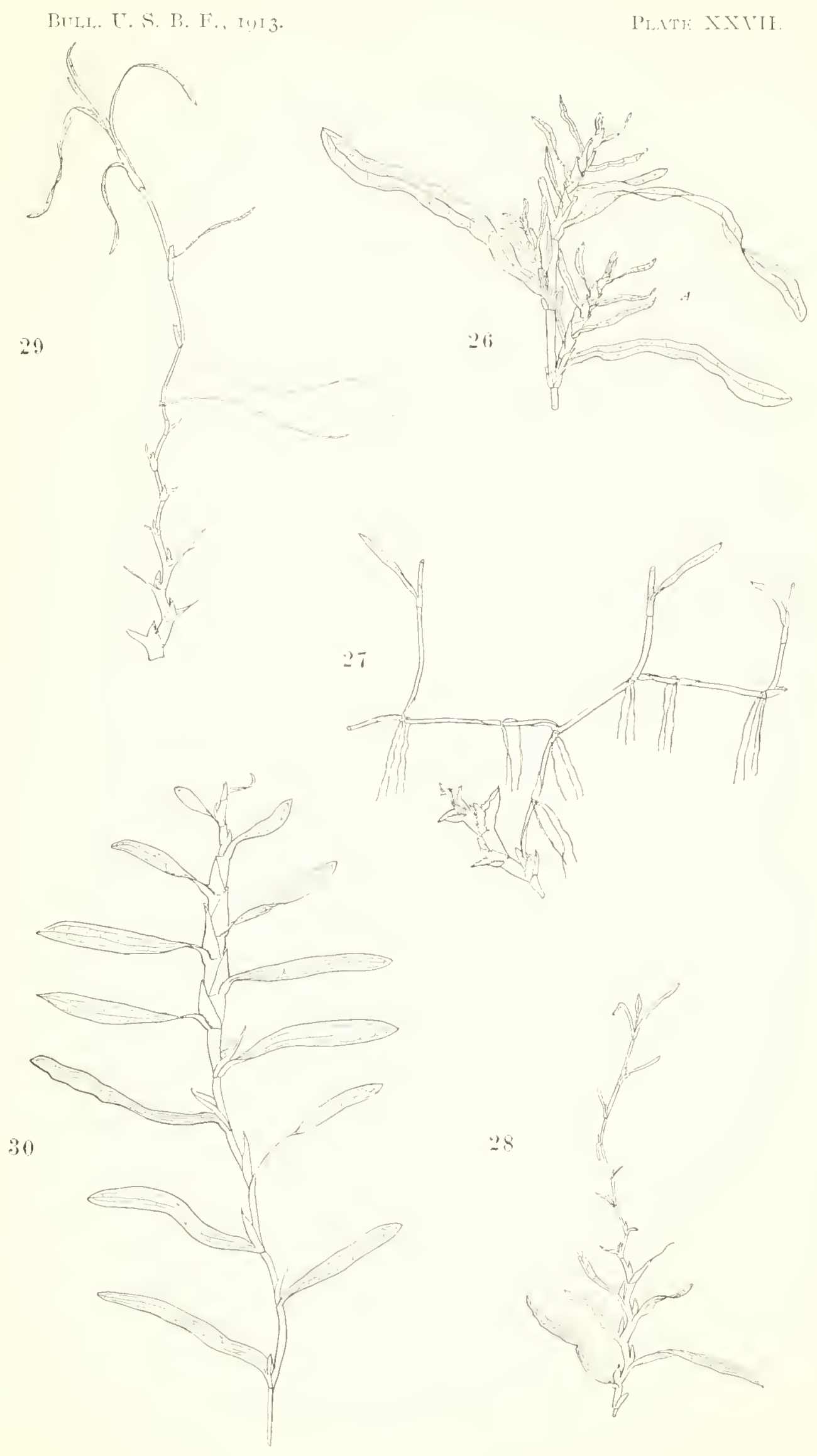





$$
V
$$



IHIIL. IT. S. IS. I IIIS.

PITTE XIIX.

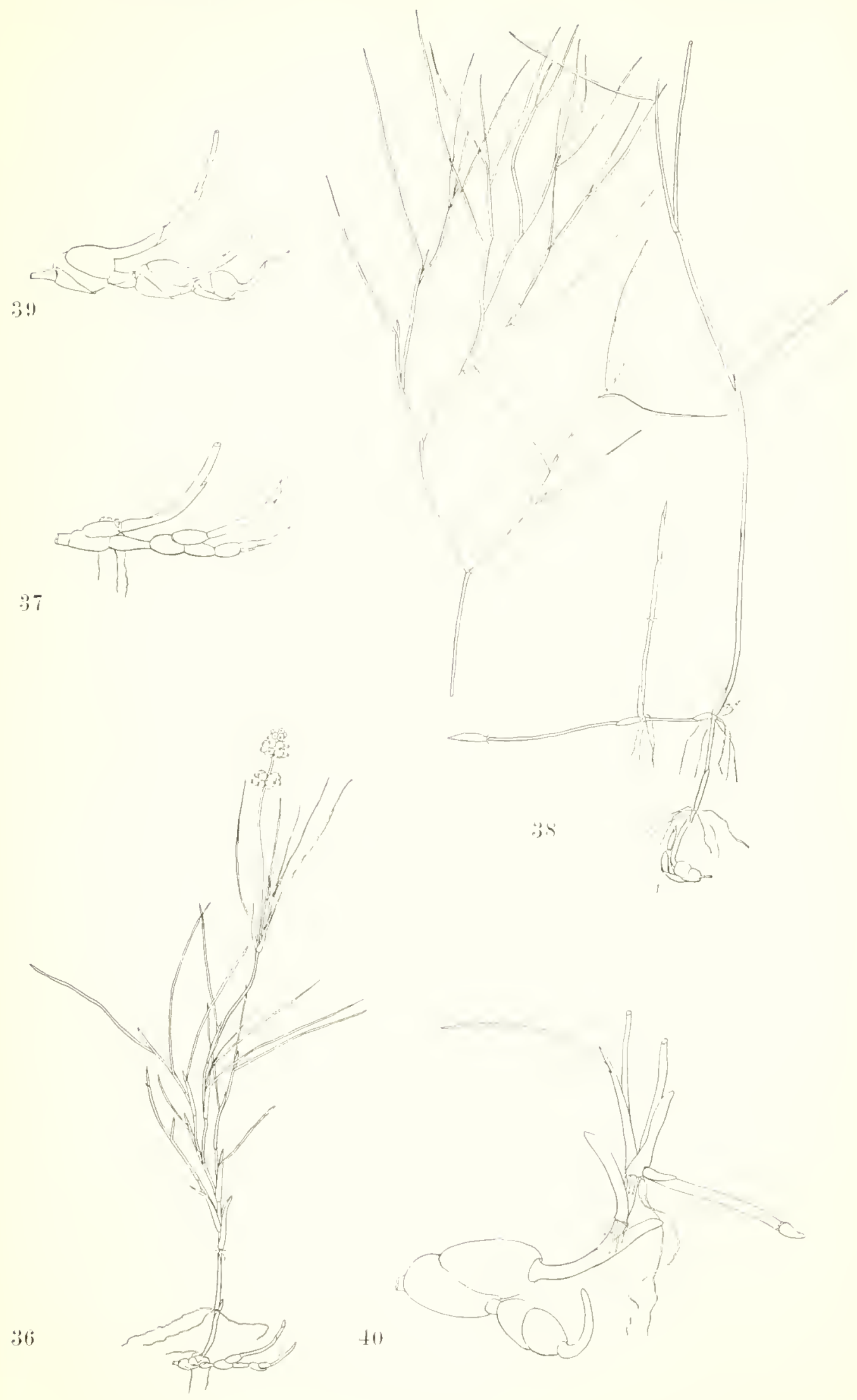





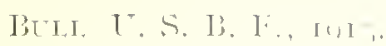

PI. TE XXX.

40
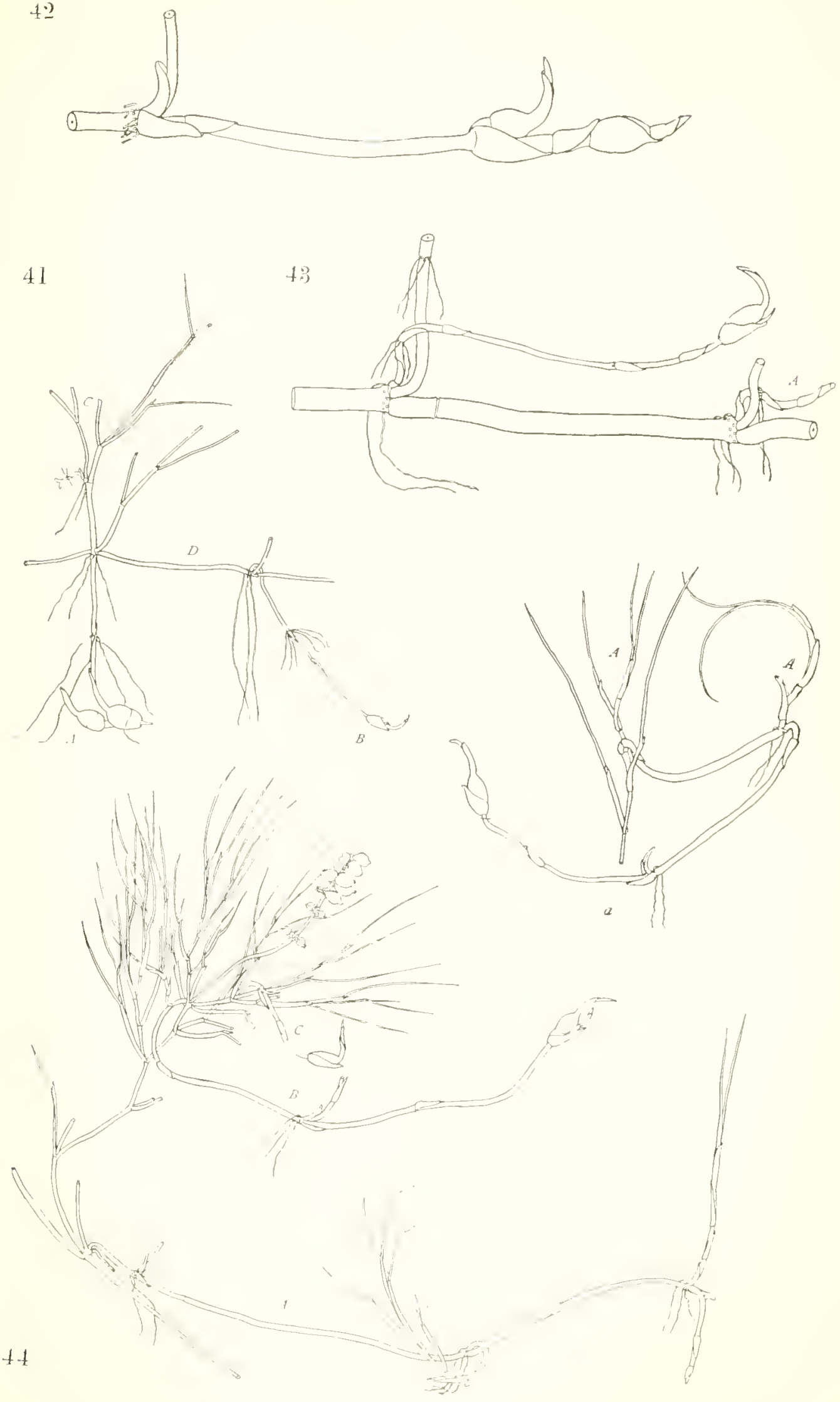



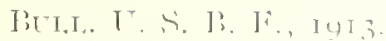

J'I'l: XXXI

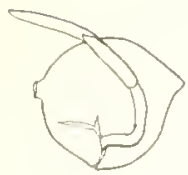

41
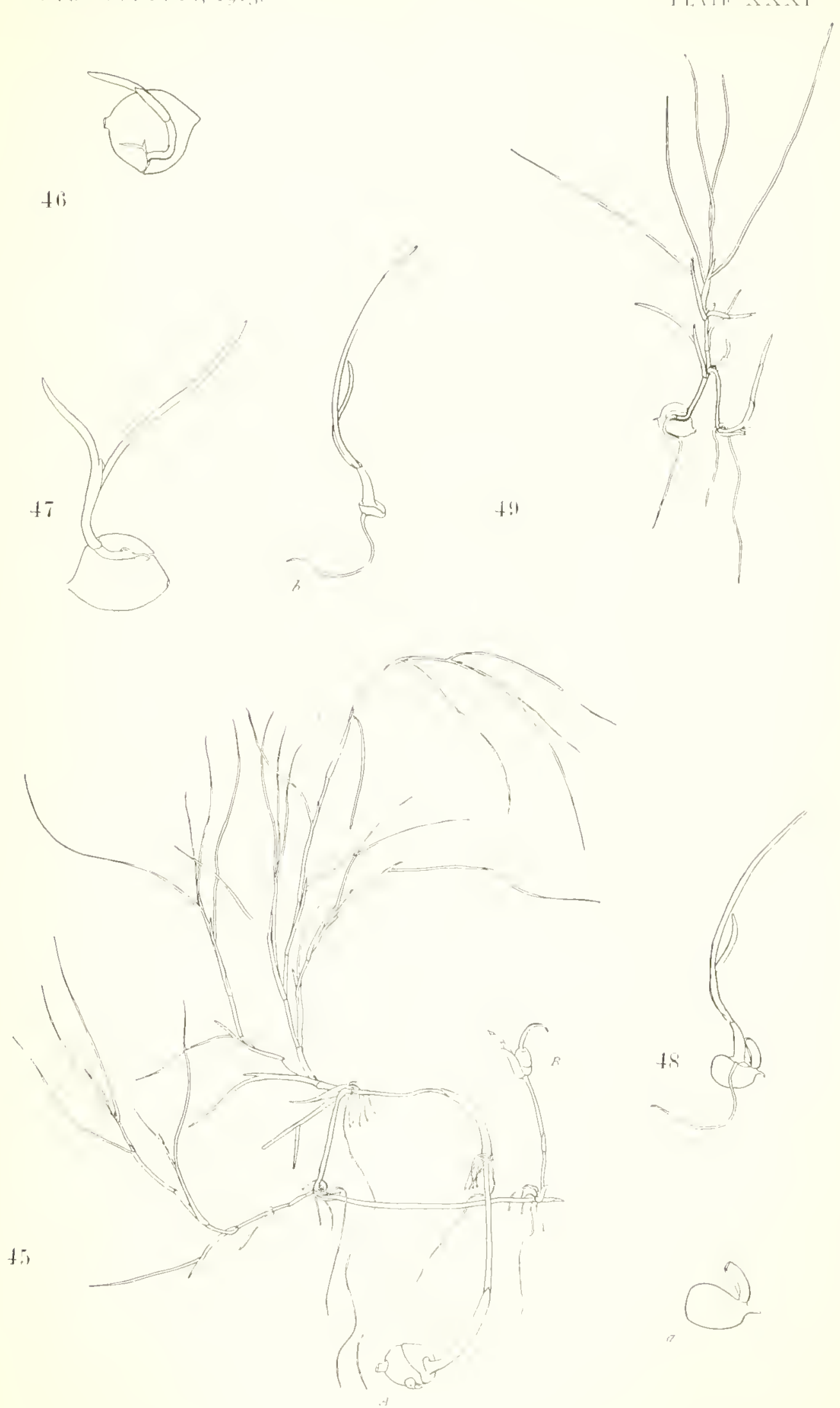

47
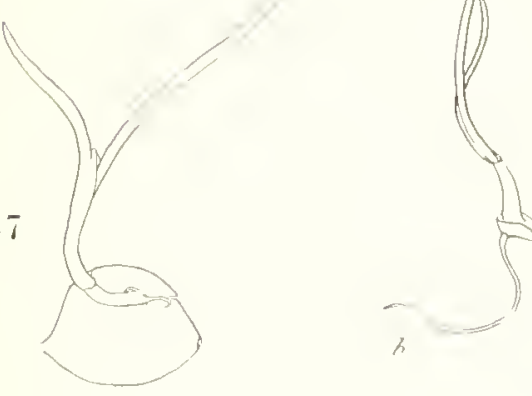

\section{$\rightarrow$}

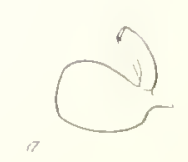





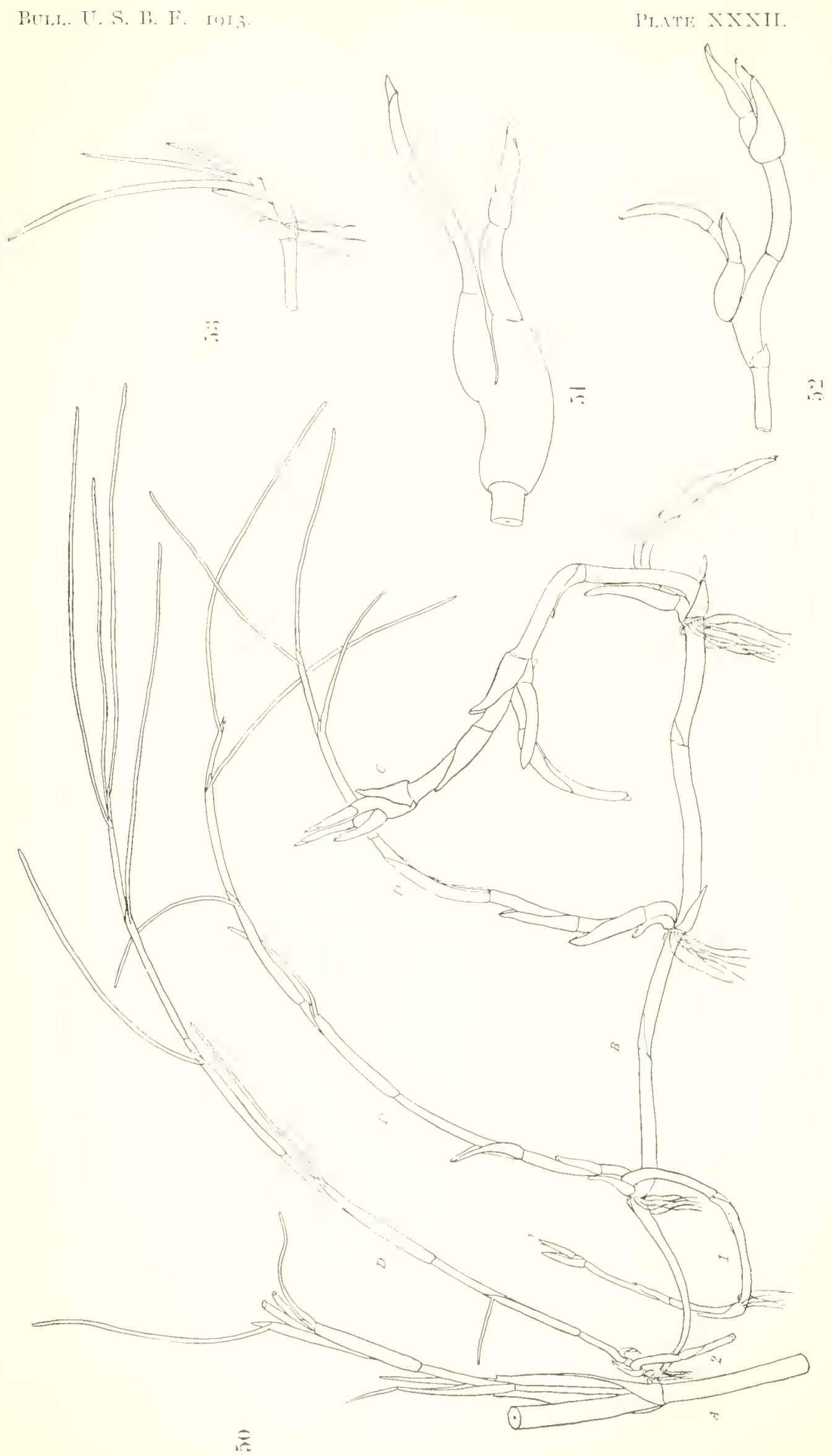



BULI. U. \$. L. F., IUI3.
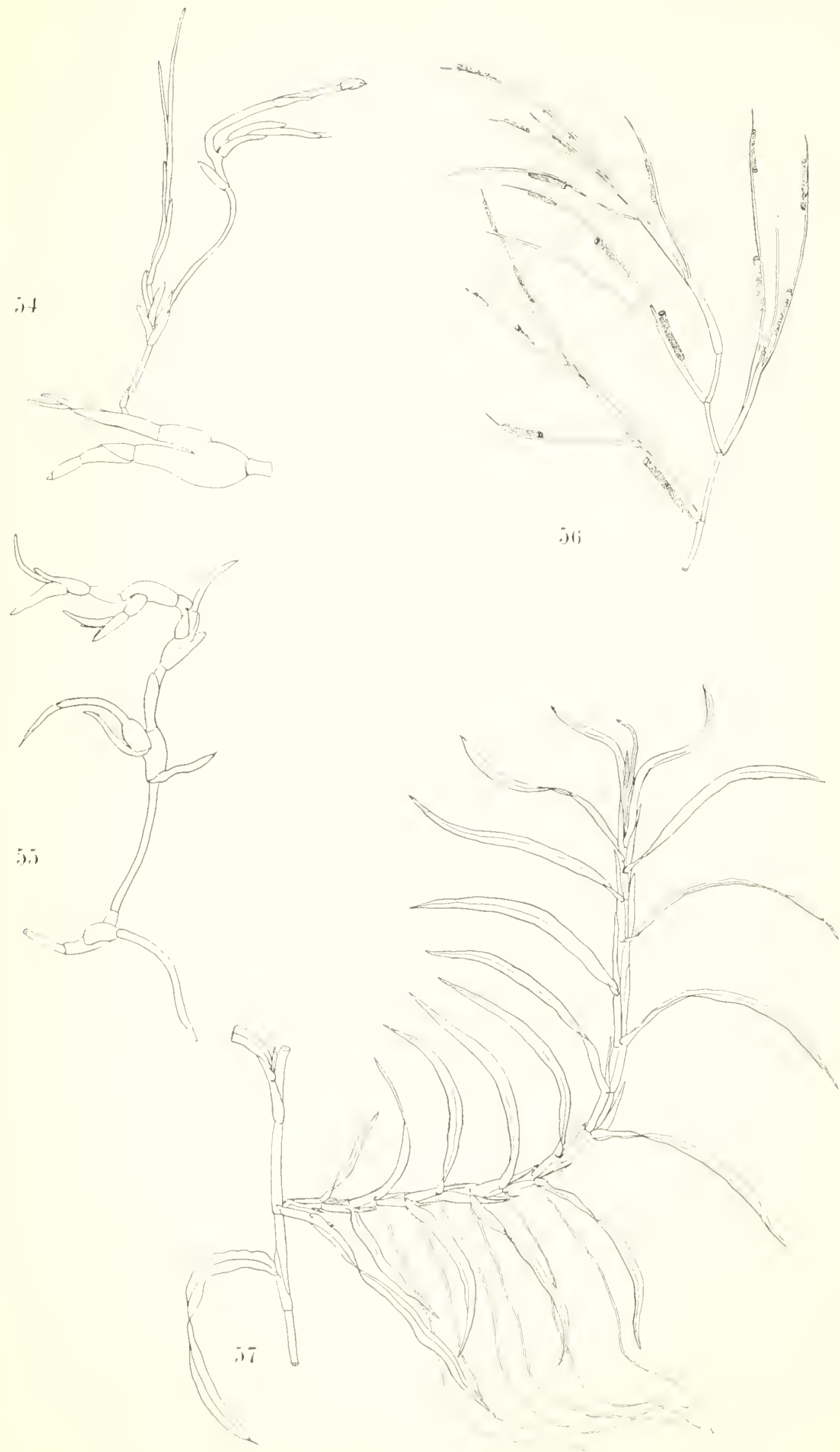

BUL1. U.S. I, F., IOI,

PLAT: XXXIT.

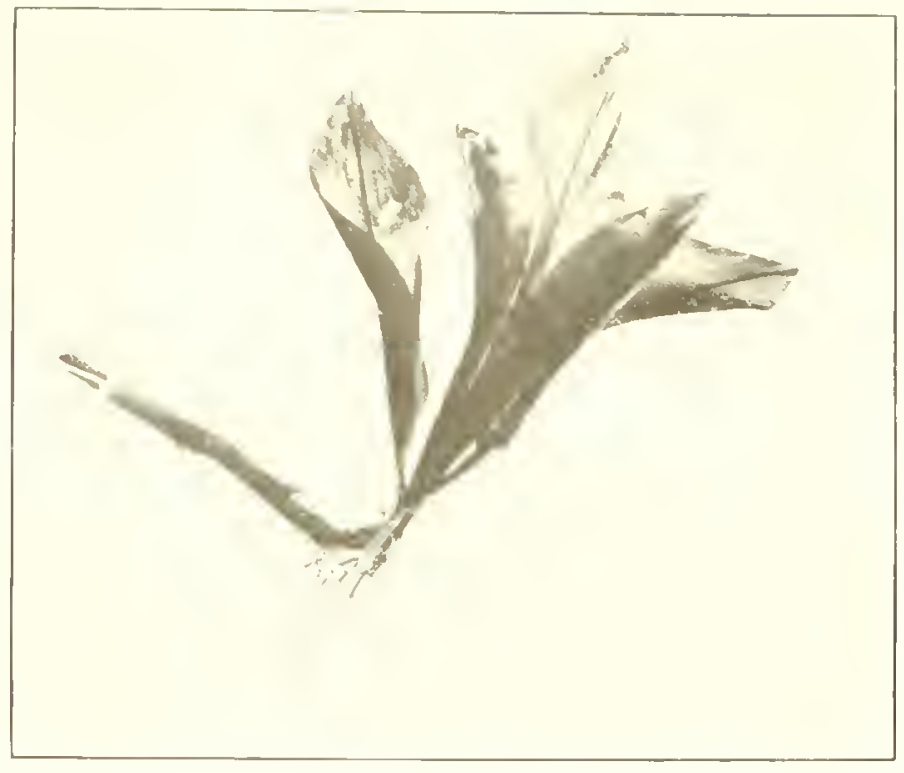

is

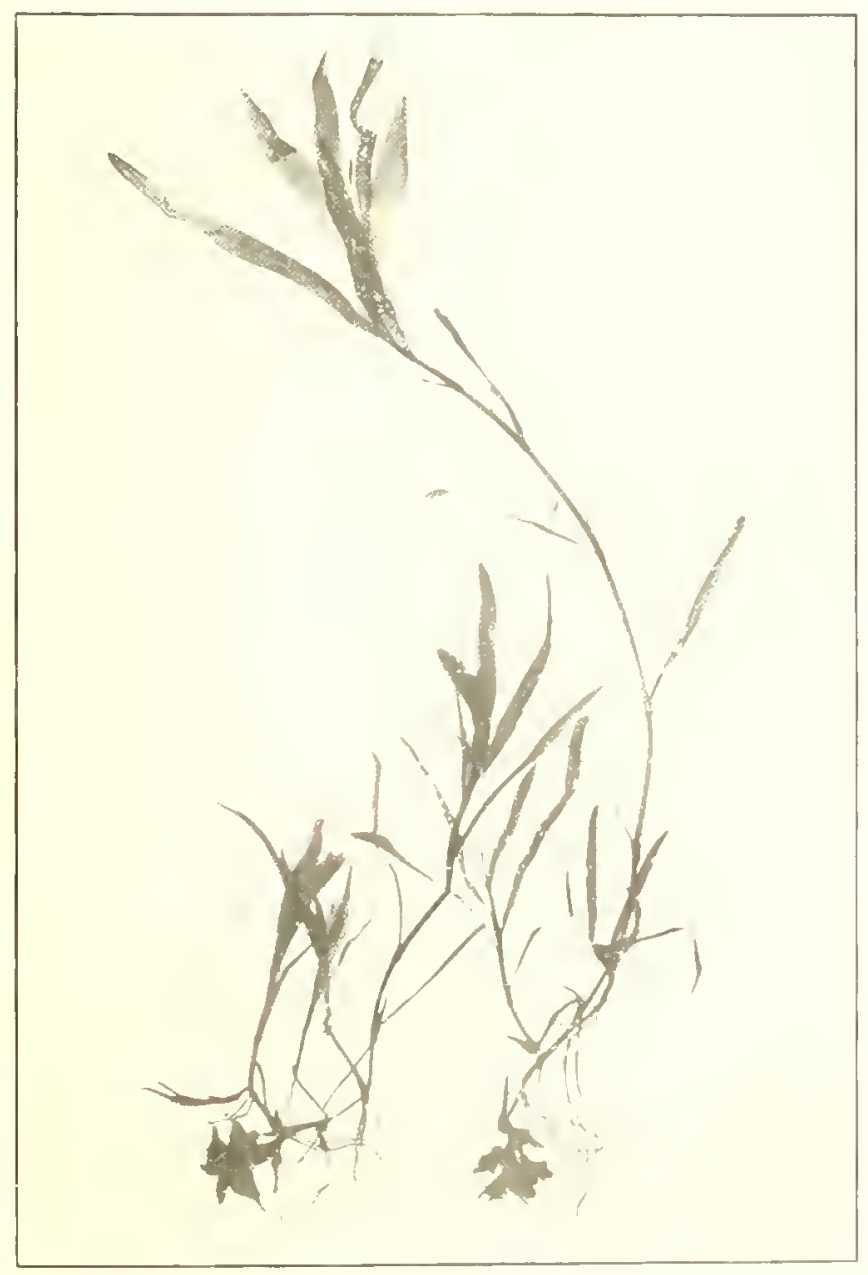

i!!

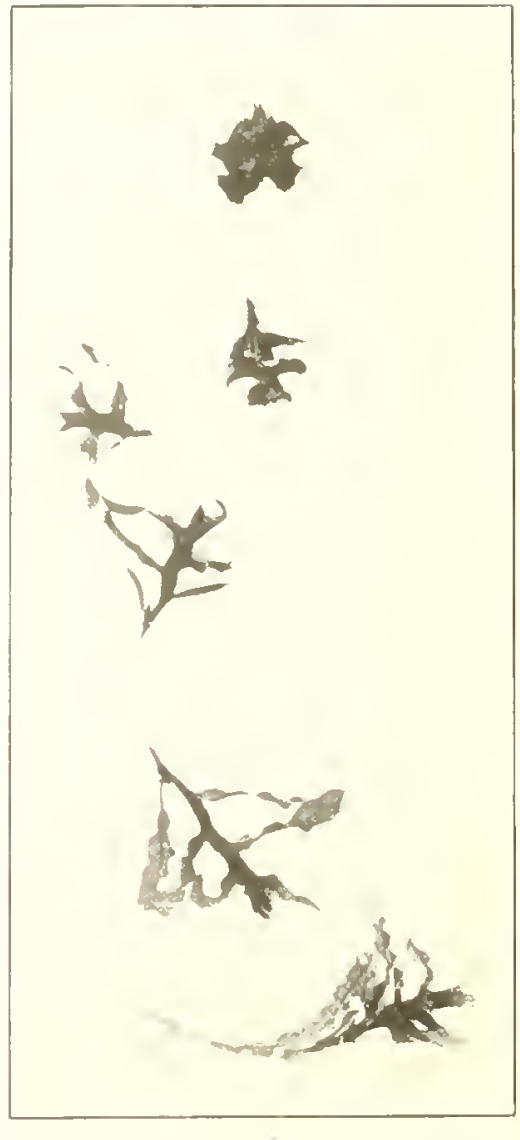

60 



$$
\text { R }
$$





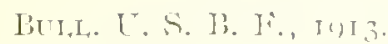

PIATE XXXII.

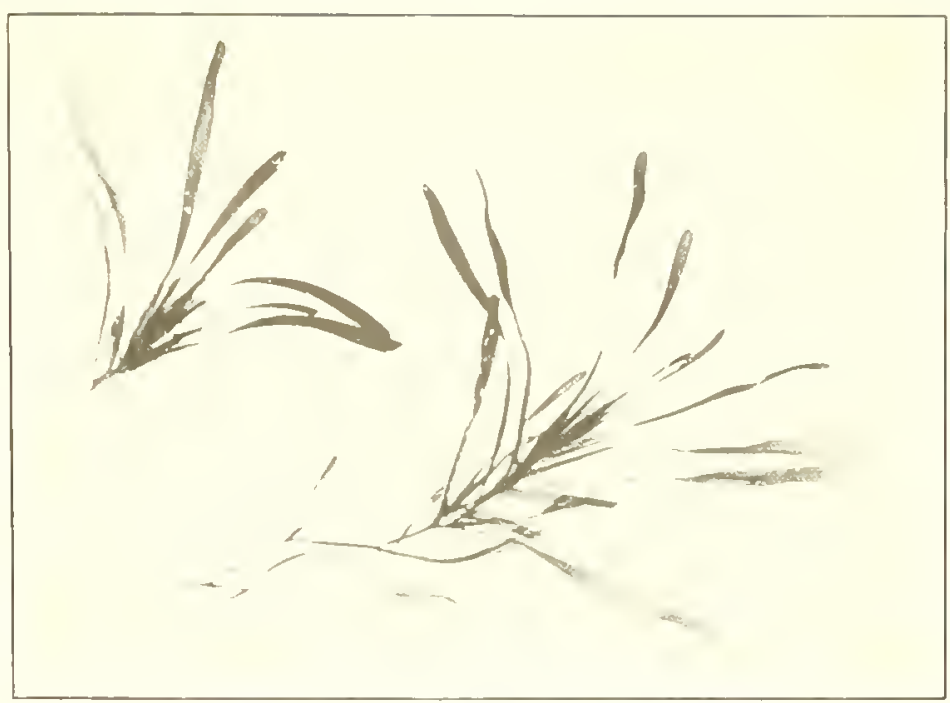

(ii)

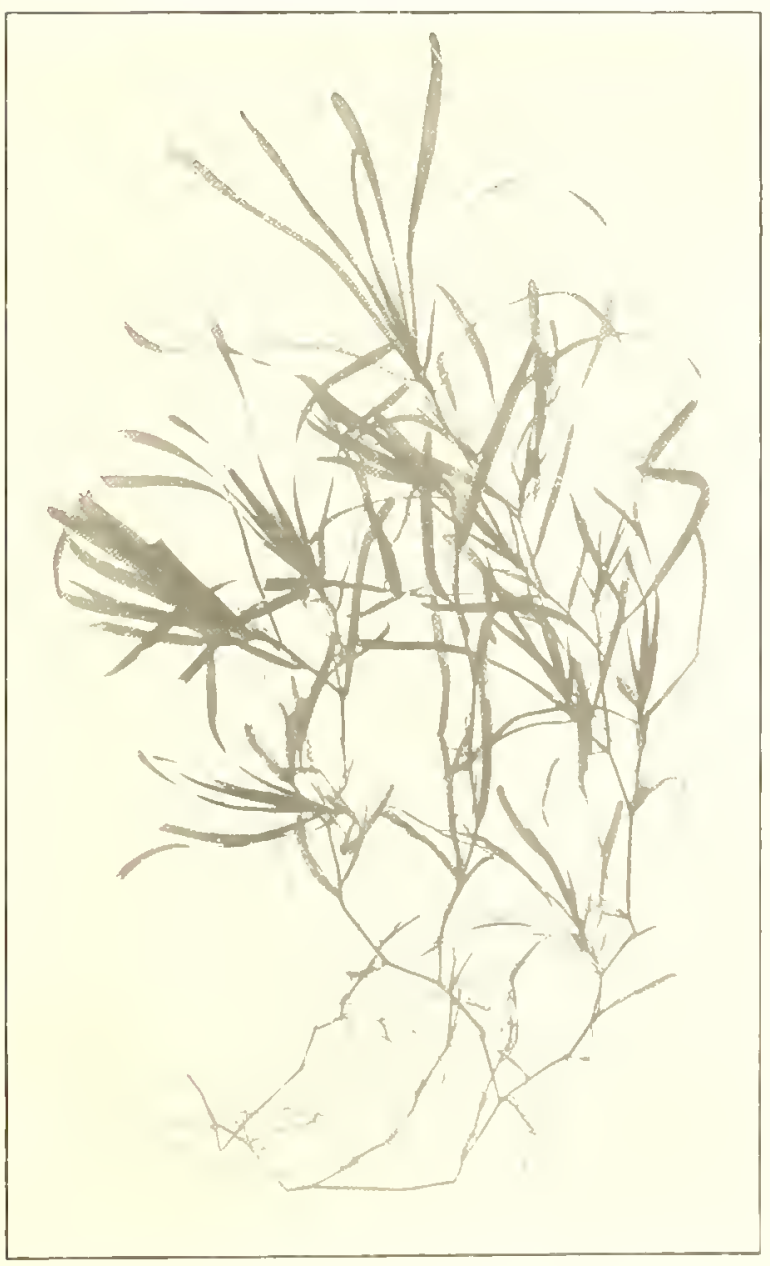

(i)

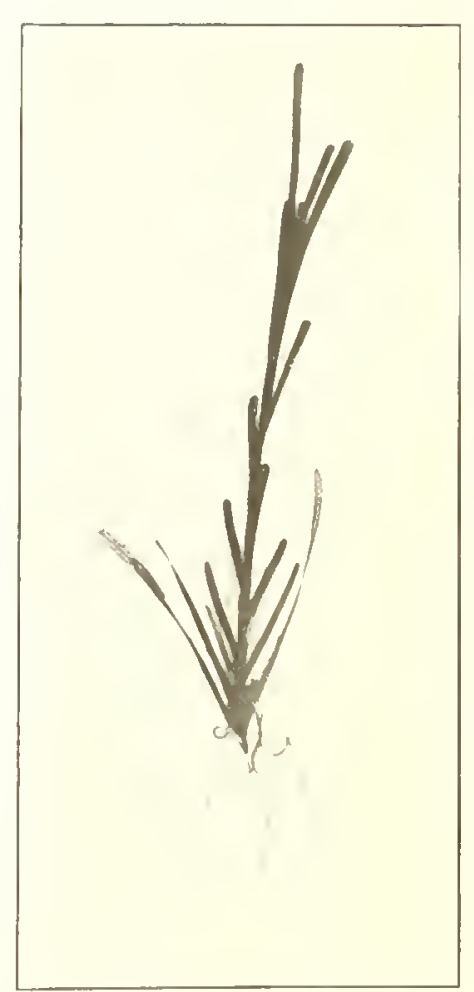

(i.) 

IタL. U. S. P. F., I9I3.

PIXIE XXXYII.

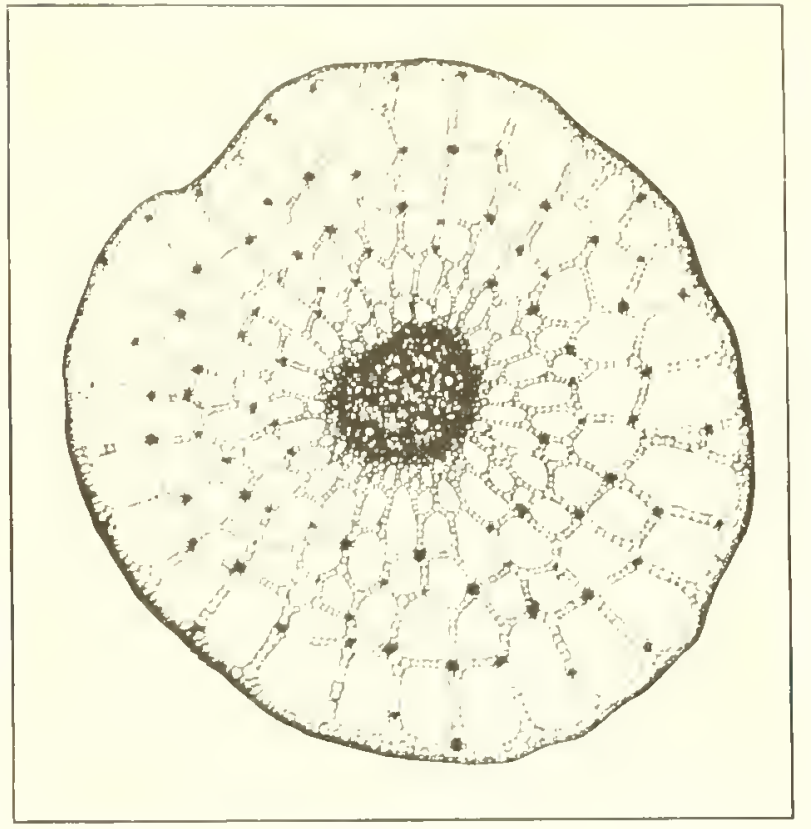

(ii)

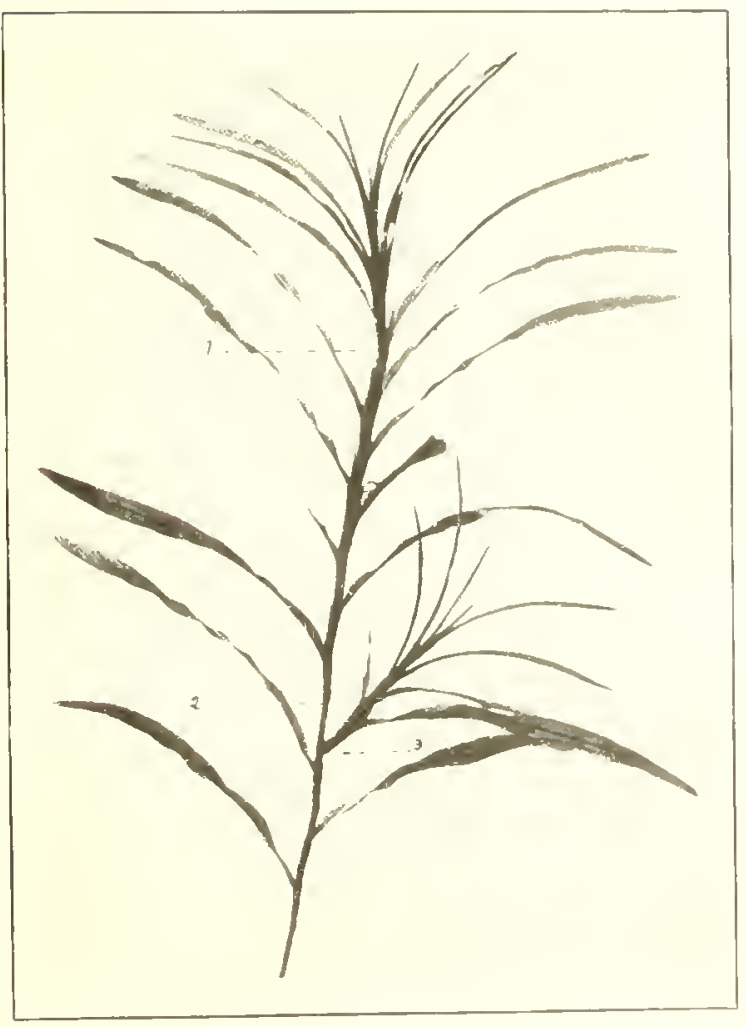

67

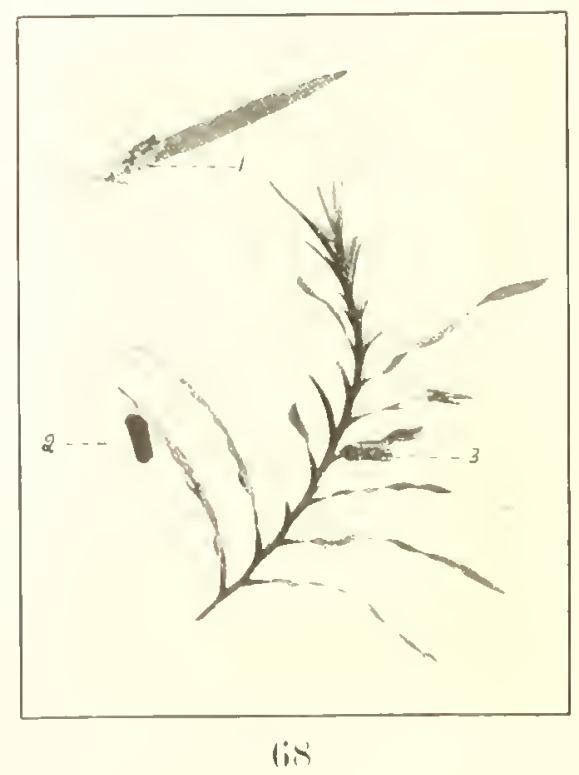





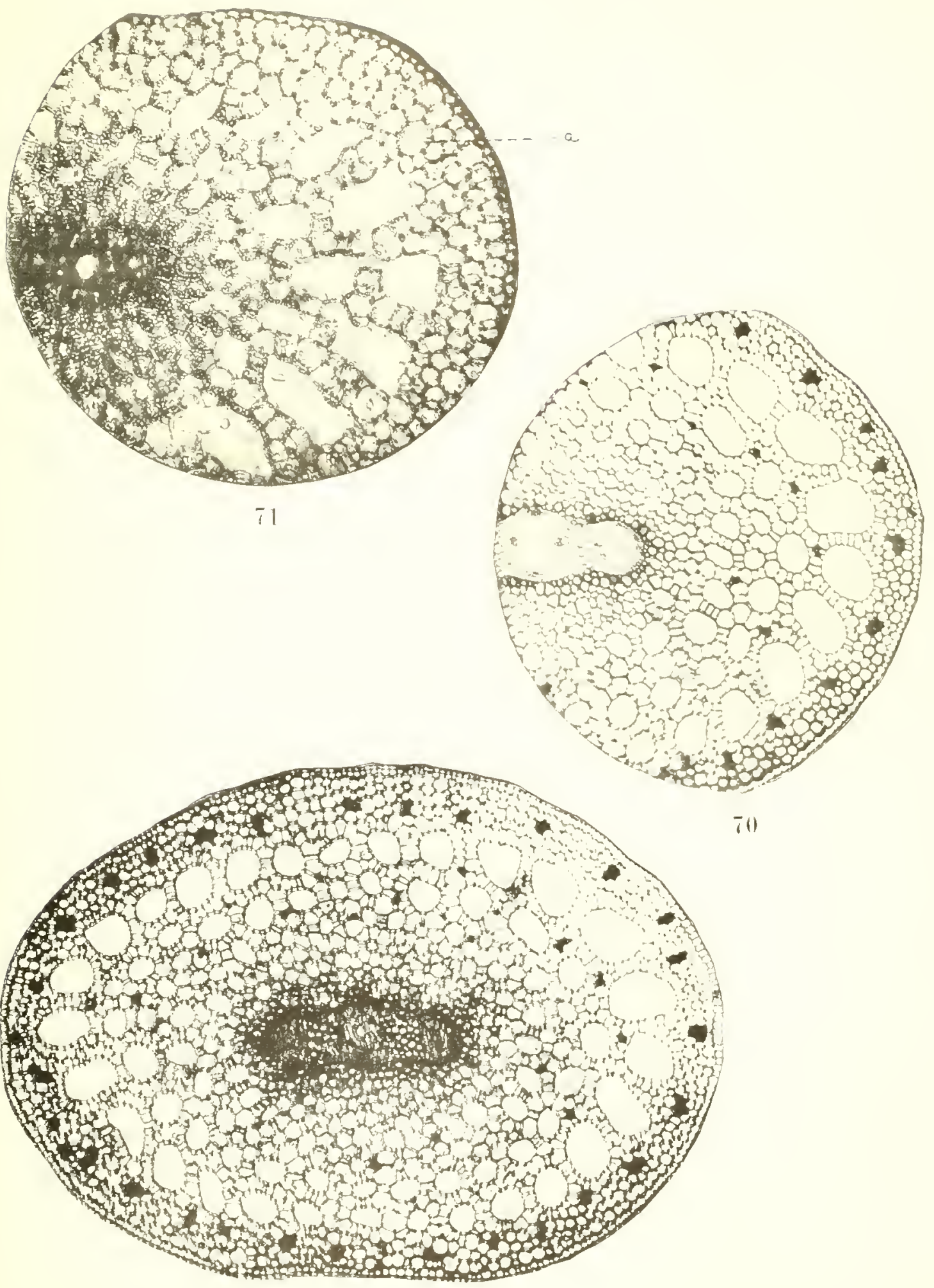



But, L. U. S. B. F⿳, IOI3.

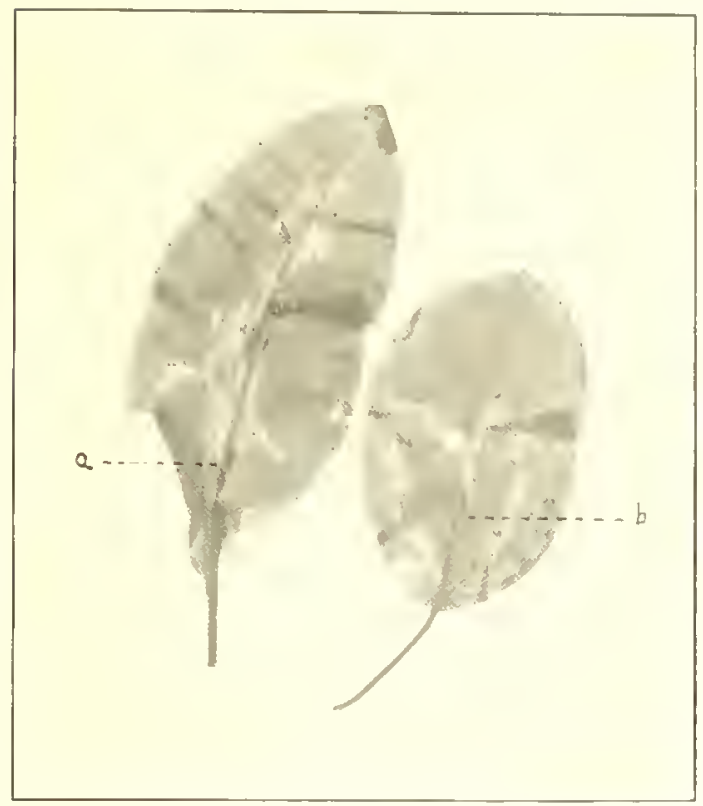

73
PITT XXXIX.
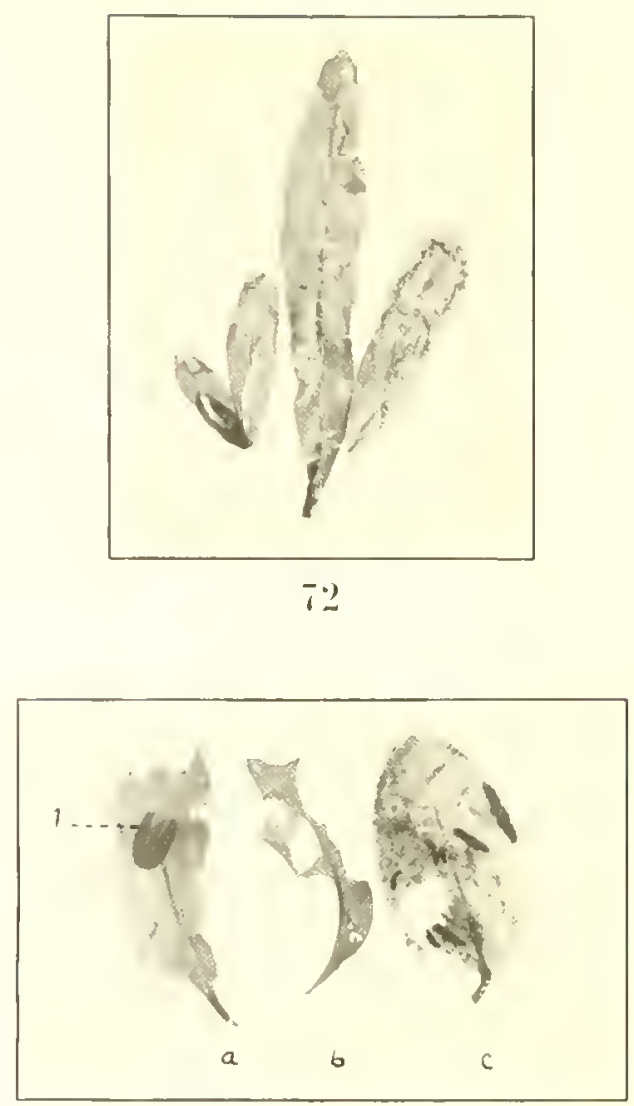

it

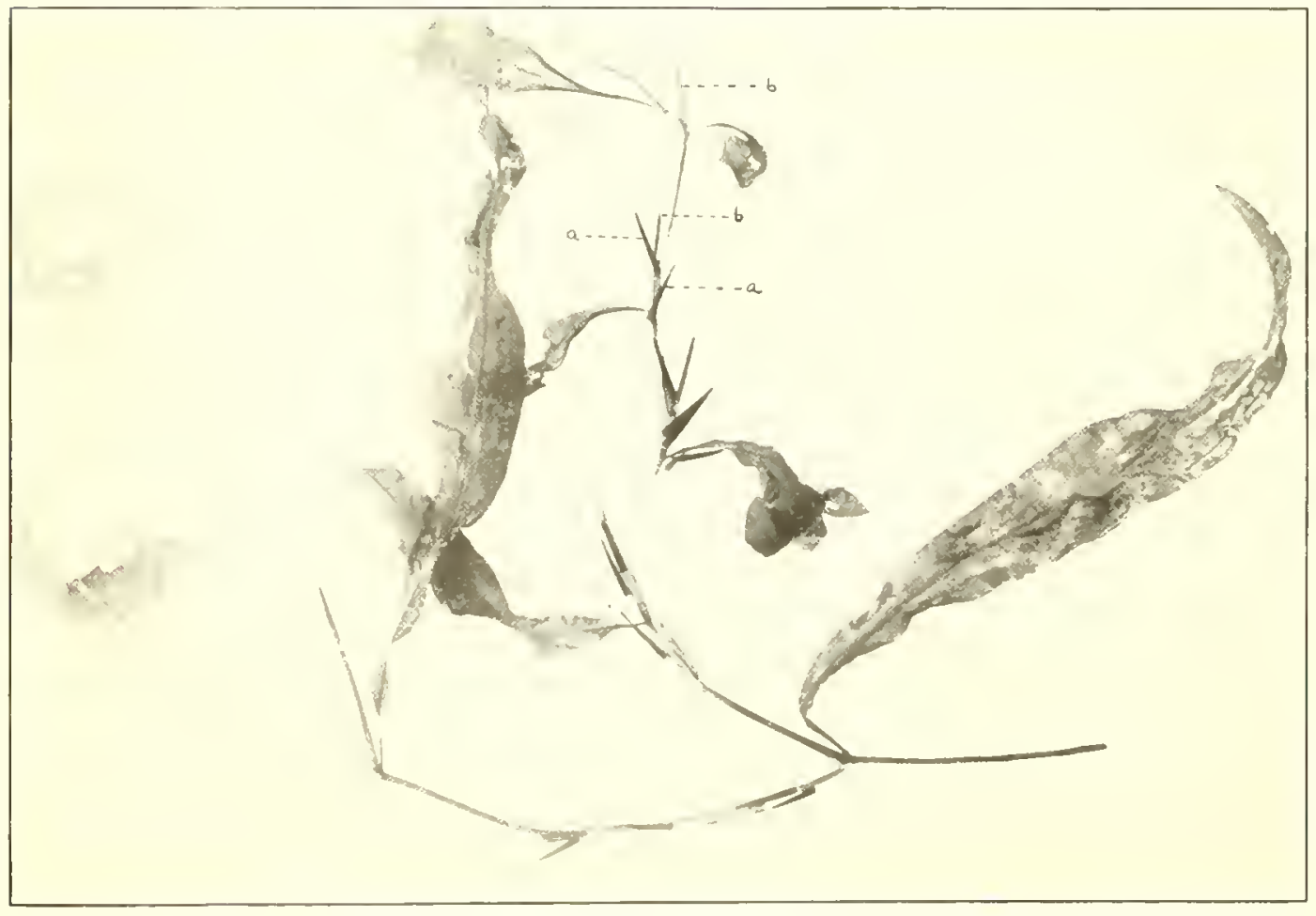




